UNIVERSIDADE DE BRASÍLIA

FaCUldade de Economia, Administração, Contabiliddade E CiênCia da INFORMAÇÃo E DOCUMENTAÇÃo (FACE)

JOSÉ TEIXEIRA MOURA

MUDANÇAS ESTRUTURAIS E ADMINISTRATIVAS E VIVÊNCIAS DE PRAZER E SOFRIMENTO NO TRABALHO NO ÂMBITO DA COORDENADORIA DE TAQUIGRAFIA DE UMA ORGANIZAÇÃO DO PODER JUDICIÁRIO FEDERAL 
JOSÉ TEIXEIRA MOURA

\title{
MUDANÇAS ESTRUTURAIS E ADMINISTRATIVAS E VIVÊNCIAS DE PRAZER E SOFRIMENTO NO TRABALHO NO ÂMBITO DA COORDENADORIA DE TAQUIGRAFIA DE UMA ORGANIZAÇÃO DO PODER JUDICIÁRIO FEDERAL
}

\begin{abstract}
Monografia apresentada no curso de Gestão Judiciária do Programa de PósGraduação em Administração da Faculdade de Economia, Administração, Contabilidade e Ciência da Informação e Documentação (FACE), da Universidade de Brasília, como requisito à obtenção do grau de Especialista em Gestão Judiciária.
\end{abstract}

Orientador: Prof. Dr. Marcus Vinicius Soares Siqueira

Brasília - DF 
A Manoelita Soares Vaz (in memorian) A Ivanilde Vieira, José Júnior e João Vítor 


\section{AGRADECIMENTOS}

A Deus, por tudo.

A minha mãe, Manoelita Soares Vaz (in memorian), pelo exemplo de dignidade.

A minha companheira, Ivanilde Vieira, pelo apoio e incentivo.

A meus filhos José Júnior e João Vítor, pela bagunça silenciosa.

Ao Comitê de Ergonomia do Superior Tribunal de Justiça, pela indispensável

contribuição.

Ao professor Marcus Vinicius Soares Siqueira, pela paciência e zelo na orientação. 


\section{LISTA DE FIGURAS}

Figura 1 - Fluxo de trabalho dos taquígrafos responsáveis pelo apanhamento............. 33

Figura 2 - Fluxo de trabalho dos taquígrafos responsáveis pela revisão...................... 33

Figura 2 - Fluxo de trabalho dos taquígrafos responsáveis pela supervisão.................. 34

Figura 4 - Quadro comparativo dos entrevistados.................................................... 36 


\section{RESUMO}

O presente trabalho pretende analisar as mudanças estruturais e administrativas implantadas na coordenadoria de taquigrafia de uma organização do Poder Judiciário Federal e as vivências de prazer e sofrimento em decorrência dessas mudanças sob o enfoque do imaginário organizacional moderno. Pretende-se analisar de que forma mudanças como o corte de benefícios e a introdução do controle eletrônico de freqüência, além das mudanças no mobiliário e a diminuição do espaço físico, influenciaram no comportamento dos servidores. Além disso, analisaremos também as estratégias individuais e coletivas de defesa desenvolvidas pelos trabalhadores. Buscaremos pesquisar as causas da relação prazer/sofrimento humano no trabalho à luz dos novos conceitos e paradigmas da administração pública. Como objetivos específicos, pretendemos pesquisar as razões/necessidades das mudanças e analisar as reações dos servidores a essas mudanças, suas implicações no ambiente de trabalho e nas relações interpessoais. A pesquisa foi feita por meio de entrevistas semi-estruturadas e aplicação de questionários em uma organização do Poder Judiciário Federal, sediada no Distrito Federal. Participaram da pesquisa 14 (quatorze) servidores, analistas e técnicos judiciários, todos pertencentes ao quadro de pessoal da referida organização, entre 18 e 30 de novembro de 2008. Verificou-se que as mudanças estruturais e administrativas implantadas deram origem a inúmeras relações de prazer/sofrimento. Este trabalho, portanto, poderá contribuir para estudos posteriores acerca do tema e poderá provocar uma reflexão, principalmente dos gestores do serviço público.

Palavras-chave: mudança; prazer; sofrimento; trabalho; estratégia de defesa. 


\section{SUMÁRIO}

1 INTRODUÇÃO

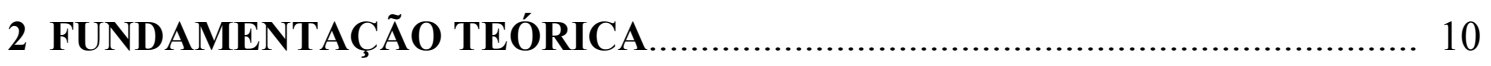

2.1 O trabalho no setor público à luz da reforma gerencial......................................... 10

2.2 As mudanças e seus efeitos para os indivíduos....................................................... 17

2.2.1 Mudanças administrativas/gerenciais. Como? Por quê? ……………………….... 19

2.2.2 Mudanças no ambiente físico de trabalho........................................................... 20



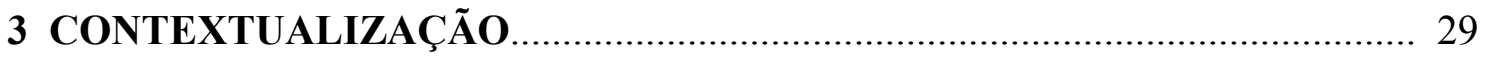

3.1 A Organização pública federal ............................................................................. 29

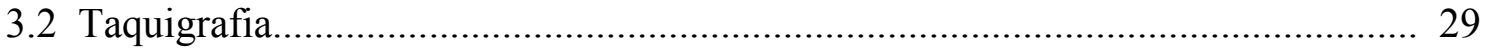

3.3 Coordenadoria de taquigrafia.................................................................... 30



4.1 Instrumento da coleta de dados....................................................................... 36

5 PRAZER E SOFRIMENTO NO TRABALHO................................................. 39

5.1 Significado do trabalho.................................................................................. 39

5.2 Relações de prazer e sofrimento no trabalho............................................................. 41

5.3 Organização do trabalho.................................................................................. 43

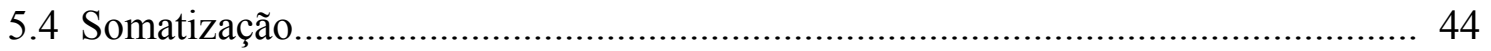

5.5 A Influência das mudanças............................................................................... 46

5.6 Estratégias de enfrentamento........................................................................... 48



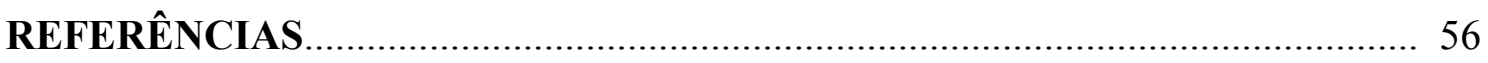




\section{1 - INTRODUÇÃO}

Um homem se humilha

Se castram seus sonhos

Seu sonho é sua vida

E sua vida é o trabalho

E sem o seu trabalho

$O$ homem não tem honra

E sem a sua honra

Se morre, se mata

Não dá pra ser feliz.

(GONZAGUINHA - Guerreiro Menino)

Sofre-se no trabalho. É pressão por todos os lados. Sofre-se por não ter trabalho e também quando se tem. Mas, como diz o poeta Gonzaguinha, "sem o seu trabalho, o homem não tem honra". As mudanças no ambiente de trabalho são implantadas, na maioria das vezes, verticalmente, de cima para baixo, sem espaço para discussão. Isso causa sofrimento. Há mudanças, no entanto, que causam prazer.

O prazer/sofrimento daí decorrente é sentido de diferentes formas. Depende de cada um, de seus sonhos, projetos, desejos, aspirações, necessidades, pontos de vista, enfim, da história de vida de cada partícipe. As organizações, com raras exceções, não consideram o indivíduo em sua totalidade. Buscam resultados, metas, números, recordes. Os gerentes, atores desse processo, cumprem o que lhes é determinado, sem questionar as consequiências de suas ações. O sujeito, percebendo-se impossibilitado de operar as transformações necessárias, aquieta-se, acomoda-se, ensimesma-se em estratégias individuais de defesa. Há assédio moral. Há conflitos. Há medo.

Neste estudo, pretende-se discutir as mudanças estruturais e administrativas implantadas na coordenadoria de taquigrafia de um tribunal superior e suas conseqüências no ambiente de trabalho. Como as profundas alterações no processo de produção de notas taquigráficas - que deixou de ser quase artesanal para ser altamente informatizado - foram recebidas pelos servidores? De que forma as mudanças estruturais e administrativas, como o corte de benefícios e a introdução do controle eletrônico de frequiência, além das mudanças no mobiliário e a diminuição do espaço físico, influenciaram no comportamento dos servidores? Quais as estratégias individuais 
e coletivas de defesa desenvolvidas pelos trabalhadores da referida coordenadoria? Como as modificações instituídas no processo de produção de notas taquigráficas e as mudanças estruturais/administrativas ali implementadas foram percebidas pelos servidores? Até que ponto a atual organização do trabalho acarreta em vivências de prazer e sofrimento?

O objetivo geral é pesquisar as causas da relação prazer/sofrimento humano no trabalho à luz dos novos conceitos e paradigmas da Administração Pública. Pesquisaremos também as mudanças estruturais e administrativas implantadas na coordenadoria de taquigrafia da organização e sua relação com as vivências de prazer e sofrimento no trabalho no âmbito dessa coordenadoria.

Como objetivos específicos, pretende-se pesquisar as razões/necessidades das mudanças e analisar as reações dos servidores a essas mudanças, suas implicações no ambiente de trabalho e nas relações interpessoais.

O estudo será dividido em: parte introdutória, onde o problema será contextualizado; fundamentação teórica, onde será analisado o trabalho no setor público à luz da reforma gerencial, contendo uma descrição mais detalhada dos objetivos que nortearam essa reforma, notadamente no serviço público publico federal, e as mudanças estruturais e administrativas, onde são examinadas as necessidades das mudanças e suas consequiências nos atores do processo. A seguir, são apresentadas as reações dos trabalhadores sob a perspectiva da Psicodinâmica do Trabalho, do Custo Humano do Trabalho e das Vivências de Bem-Estar e de Mal-Estar no Contexto do Trabalho. Procura-se caracterizar de forma sucinta a arte/técnica de taquigrafar, bem como a contextualização da instituição pesquisada, em especial a sua coordenadoria de taquigrafia. A terceira parte trata da metodologia utilizada para investigar as relações de prazer/sofrimento na coordenadoria objeto deste estudo, quando os resultados são apresentados e discutidos e oferecidas algumas considerações finais. 


\section{2 - FUNDAMENTAÇÃO TEÓRICA.}

\section{1 - O trabalho no setor público à luz da reforma gerencial}

Havia, há algum tempo no Brasil, um conflito entre os defensores do Estado onipotente, gigante, em que o administrador desconhecia o ambiente externo, vale dizer, o cliente, e onde predominavam o paternalismo nas relações de trabalho, a falta de ousadia no processo decisório, a falta de comprometimento dos gestores e servidores, bem como o apego às regras e procedimentos e ao poder, além da falta de uma política estratégica de recursos humanos - herança do regime ditatorial e de alguns equívocos na interpretação da teoria socialista - e os que defendiam a idéia do Estado minimalista, enxuto, com funções reduzidas, onde seriam valorizados a competência, a dedicação e o bom desempenho, onde seriam estimuladas a participação e a criatividade, além da adoção de uma política centrada na redução de custos e na garantia da prestação de um serviço público de qualidade e que garantisse princípios de autonomia e uma reestrutura do desenho organizacional - visão fragmentada do conceito neoliberal.

Felizmente, diante dessa dicotomia, prevaleceu a tese de que a modernização do Estado tem que ser um processo de constituição da cidadania e de melhor utilização dos recursos públicos. O resultado tem que ser a satisfação dos usuários com a qualidade do serviço público. Para tanto, o Estado deve alterar suas políticas protecionistas, substituindo-as por medidas que induzam as empresas a serem mais competitivas no novo ambiente econômico mundial, sem, contudo, caminhar no sentido do liberalismo desenfreado, onde o mercado tudo regula. A recente crise econômico/financeira mundial (crise do capitalismo?) é uma clara demonstração de que a economia de mercado, liberal às escancaras, não é a cura para todas as mazelas.

A atenção do Estado deve estar voltada primordialmente para a área social, assegurando a universalidade dos serviços de saúde e educação e para a criação de instrumentos que ajudem a promover o desenvolvimento econômico. (FERREIRA (1996) 
A autora ainda ensina que:

Em vez da intervenção direta como produtor, o aparelho estatal deve concentrar suas atividades na regulação. $O$ governo não pode ser uma empresa, mas pode ser mais empresarial, isto é, pode ser mais ágil e flexível diante das mudanças ambientais que atingem todas as organizações. (FERREIRA (1996)

O decantado processo de modernização do Estado trouxe à baila conceitos como flexibilidade (das instituições e da relação do Estado com seus servidores), inovação (nos processos de tomada de decisão e nas formas de produção dos serviços públicos) e descentralização (municípios, estados e União), que desempenham um papel fundamental na tarefa de aproximar o setor público de seus usuários, já que a atuação do governo no âmbito federal, estadual e municipal favorece (deveria favorecer), não somente o vínculo entre o Estado e o cidadão, mas também a capacidade total do sistema para ser gerenciado nessa direção.

Não se pode perder de vista, assim, a necessária profissionalização do trabalho no setor público. Há que se ter instrumentos de controle que possibilitem o desenvolvimento das atividades pelo caminho da lei, buscando evitar abusos e corrupção. Assim, há que se estabelecer uma continuidade no modo de operar dos órgãos públicos para além das mudanças políticas ocasionais, conjunturais, os chamados modismos.

O Estado deve ser/tem que ser maior que qualquer governo.

Diante dessa nova forma de apresentação do Estado, os servidores passaram a desempenhar papel fundamental. Imediatamente, emergiu a cobrança por servidores mais qualificados, comprometidos e preparados para o trabalho em equipe, para utilizar modernos instrumentos tecnológicos e para superar desafios. São avaliadas competências, e não pessoas. Normas, costumes e procedimentos tradicionais são questionados, postos em xeque. O processo de fortalecimento das gerências, com mais poder, autonomia e maior profissionalismo, por sua vez, vem acompanhado por questionamentos e resistências, o que acarreta, não raro, inimizades e incompreensões. Para Ferreira (1996), "mais que uma reforma administrativa, era preciso uma reforma na mentalidade administrativa, na maneira de ver e atuar institucionalmente". Necessária se fez, então, uma mudança no perfil dos atores, quer no quesito qualificação (capacidades gerenciais, de liderança, de trabalho em equipe), quer no quesito postura diante das 
inevitáveis reformas estruturais e administrativas, já que mudaram as prioridades e objetivos, e maior enfoque foi dado à eficiência e à eficácia.

Os desafios de uma gestão pública moderna são: recriar uma racionalidade microeconômica; incentivar um maior compromisso com a gestão; procurar um novo equilíbrio entre a flexibilidade e os regulamentos; estabelecer uma nova relação com a sociedade e revitalizar o sentido da função pública. Para tanto, o trabalho no setor público teve que se adaptar a essa nova realidade. Surgiram novas formas de gerenciamento. A avaliação deixou de ser centrada nas pessoas para se ocupar das competências. Aconteceu o questionamento de normas, comportamentos e procedimentos. (TOHÁ E SOLARI, 1997)

A mudança de mentalidade administrativa em relação ao serviço público requer disposição, sobretudo dos gestores, para remover valores, crenças, concepções e paradigmas, muitas vezes cristalizados, arraigados mesmo, no contexto organizacional, que podem estar na origem dos obstáculos para a aceitação/implantação do novo modelo. Nesse sentido, mudança de mentalidade implica em pensar de forma diferente para agir de forma diferente. Não se mudam práticas de forma conseqüente sem mudanças de consciências.

A reforma do Estado visou conferir maior agilidade e eficácia às ações do mesmo, mudando o foco do debate dos direitos do servidor para os compromissos públicos com os direitos do cidadão, e, conseqüentemente, para a melhoria efetiva dos serviços prestados. As críticas aos serviços oferecidos pelo Estado - notadamente no que se refere ao Poder Judiciário - não são poucas. Vão desde a escassez à baixa qualidade. No caso do Poder Judiciário, impera a morosidade, resultado, principalmente, do emaranhado legislativo que possibilita inúmeros recursos com caráter nitidamente protelatório. Além disso, há lugares em que a presença do Estado é extremamente discutível. São atividades eminentemente características da iniciativa privada. As reformas estruturais, portanto, podem oferecer as condições necessárias para ampliar a governabilidade e recuperar a confiança da sociedade nas instituições.

Acontece que diante de uma cultura política grandemente enraizada em uma herança colonial patrimonialista, em que o Estado sempre foi o grande provedor, qualquer tentativa de modificação, de reforma, mesmo que indiscutivelmente necessária, com um mínimo que seja de profissionalismo, gera enormes resistências de caráter legal e/ou corporativista, oriundas da classe política ou de interesses de grupos 
organizados, até porque no Estado provedor torna-se difícil estabelecer com clareza quais são os limites entre o público e o privado. A mudança e a nova postura organizacional, em função disso, passam a ser um processo contínuo e permanente nas instituições, e não um fenômeno transitório e fragmentado, além de se constituir em uma exigência, em verdadeira questão de sobrevivência institucional.

A busca por resultados imediatos deve ser/tem que ser substituída por políticas de longo prazo (continuidade). A gerência pública passa a ser uma peça fundamental nessa nova forma de entender a modernização do Estado. Procura-se criar condições equivalentes à racionalidade das empresas privadas sem desconsiderar a especificidade do setor público. É necessária uma cultura organizacional que privilegie o trabalho em grupo, autônomo, profissional, em detrimento do apego às normas e à submissão hierárquica, que, na maioria das vezes, inibe a capacidade criadora, resultado da inteligência prática.

Osborne e Gaebler (1994) propõem dez princípios básicos que devem nortear uma reforma (por eles chamada reinvenção) do governo, quais sejam:

- Competição entre os prestadores de serviço;

- Poder aos cidadãos, transferindo o controle das atividades à comunidade;

- Medir a atuação das agências governamentais através dos resultados;

- Orientar-se por objetivos, e não por regras e regulamentos;

- Redefinir os usuários como clientes;

- Atuar na prevenção dos problemas mais do que no tratamento;

- Priorizar o investimento na produção de recursos, e não em seu gasto;

- Descentralização da autoridade;

- Preferir os mecanismos de mercado às soluções burocráticas;

- Catalisar a ação dos setores público, privado e voluntário. (OSBORNE E GAEBLER, 1994)

Os autores exploram a idéia do governo empreendedor como sendo aquele que transfere recursos de setores menos produtivos para setores mais produtivos. Assim, reinventar significa adequar-se à era da informação, desenvolver a capacidade criativa $\mathrm{e}$ inovadora para enfrentar as limitações impostas pela forte cultura burocrática dominante. 
Goodsell (1993) no seu texto Reinvent government or Rediscover it, critica as propostas de Osborne e Gaebler, dizendo que eles não conseguiram entender a natureza da gestão democrática na administração pública, critica o excessivo monopólio estatal, o alto grau de burocratização, a falta de incentivos para o sucesso e a impunidade nos casos de fracasso, além da ausência de mecanismos que encorajem processos criativos voltados para a inovação.

Finaliza o autor com a apresentação do seu decálogo de como deve ser uma administração pública democrática, transcrito a seguir:

- Através de seus representantes eleitos, os cidadãos, e não os empresários, devem estar a cargo do governo;

- A função do governo é servir o interesse público, não criar reservas de mercado ou alimentar "egos empresariais";

- O governo tem que operar sob as regras da Constituição e das leis, e não a partir de missões comandadas por particulares;

- O governo pode entrar em associações com entidades privadas, sempre e quando for o sócio principal;

- $O$ governo deve ser flexível e inovador, porém, também deve ser suscetível à prestação de contas ao público;

- O governo deve buscar resultados, todavia, sem atropelar aqueles que vão desempenhar as tarefas, ou seja, os funcionários públicos;

- No governo, a conduta dos gerentes deve se submeter ao ideal de igualdade de oportunidades;

- É importante simplificar regras, contanto que se respeita a integridade dos processos legais;

- A flexibilização orçamentária é aceitável, mas não a redução de controles destinados a proteger os recursos públicos;

- Os problemas políticos devem ser solucionados com criatividade, sem, no entanto, dar vantagens a quem pode se beneficiar das mudanças. (GOODSELL, 1993)

Conforme se observa, há argumentos em todos os sentidos, para todos os gostos.

A Revista do Serviço Público (1996) traz importante contribuição de Caio Márcio Marini Ferreira para a análise do serviço público brasileiro à luz da reforma do Estado, intitulada: Crise e reforma do Estado: uma questão de cidadania e valorização do servidor, da qual destacamos alguns pontos valiosos. 
Inicialmente, o autor relata que a primeira experiência concreta de reforma administrativa no Brasil ocorreu na década de 30, no governo de Getúlio Vargas. A preocupação central era a da introdução do modelo burocrático na administração pública brasileira para enfrentar a expansão patrimonialista vigente. Foi criado o Departamento de Administração do Serviço Público (DASP), que assumiu as funções de implementar as diretrizes, supervisionar a Administração Pública e formar os administradores públicos do primeiro escalão, além de fixar o orçamento nacional.

Para Marini Ferreira, tal atitude resultou em duplo padrão: os altos administradores seguiram essas normas e se transformaram na melhor burocracia estatal da América Latina, enquanto os escalões inferiores (incluindo os órgãos da área social) foram deixados ao critério clientelista de recrutamento e à manipulação populista dos recursos públicos.

A partir de 1995, o governo Fernando Henrique Cardoso estabelece uma nova estratégia para a reforma da Administração Pública brasileira integrada a um processo mais abrangente de reforma do Estado. A Secretaria da Administração Federal é transformada em ministério. A nova pasta, além das funções tradicionais de gestão da função pública, assume o papel de coordenadora do processo de reforma do aparelho do Estado.

O autor assinala que a reforma do Estado, "mais do que um conjunto de intenções, é um processo complexo e permanente, que requer, para seu pleno desenvolvimento, objetividade, persistência e construção de uma estratégia que permita enfrentar conflitos e ambigüidades". Seu pensamento é o de que essa nova realidade exigirá um novo modelo de gerência. Mais do que gerência, um novo modelo de liderança, pois o novo contexto, caracterizado por profundas transformações, vai demandar habilidades de negociação e administração de conflitos, frustrações e resistências, como, via de regra, surge sempre diante do novo. Para ele, as reorientações na implantação do modelo gerencial tratam especificamente da necessidade de fazer evoluir o controle voltado ao cumprimento do rito burocrático na direção do controle por resultados.

E prossegue:

Sem risco de cometer exageros, pode-se afirmar que o controle, quando existe, está preocupado, tão-somente, com a legalidade da ação administrativa: o bom administrador é o que cumpre o rito, o manual, o que 
segue a cartilha, e não o que atinge os objetivos. (FERREIRA, 1996)

Seu pensamento é no sentido de que é necessário recuperar a cultura perdida do planejamento, desenvolver novos métodos e introduzir novos valores voltados para o controle dos resultados. Nesse sentido, a utilização de instrumentos como o contrato de gestão, por exemplo, pode ajudar a realizar esse importante desafio. Vale destacar que a questão não se limita a simplesmente introduzir este instrumento - pois seria apenas mais um entrave burocrático -, mas, mais do que isto, o objetivo é implantar uma nova filosofia de controle baseada na avaliação dos resultados.

Realizar um processo de transformação, que envolva mudança de cultura e atitudes não é tarefa trivial. Ao contrário, requer habilidade e liderança para a condução do processo, que, certamente, acontecerá num contexto caracterizado por resistências e ambigüidades. Toda mudança cria um clima de instabilidade, o que é natural, diante do novo, que supõe um custo inicial de aprendizado. Também, inevitavelmente associada a um processo de transformação, está a possibilidade de ganhos e perdas, na perspectiva dos atores envolvidos no processo. (FERREIRA, 1996)

E o autor arremata:

No sentido de enfrentar os obstáculos naturais, nesse contexto de mudança, torna-se fundamental estabelecer uma estratégia que viabilize o processo, por intermédio de mecanismos que neutralizem as ameaças e potencializem as oportunidades. Nos processos de transformação organizacional, tanto no âmbito da administração de empresas, quanto no da administração pública, dois são os elementos-chave, que funcionam como sujeito e objeto da mudança: quem presta o serviço e quem dele se beneficia. A mudança será sempre conduzida pelas pessoas que prestam o serviço para as pessoas que usam o serviço. No caso da administração pública, essa abordagem motiva a discussão da necessidade de construção de uma importante aliança estratégica entre servidores e cidadãos na direção de um objetivo comum, qual seja, o de (re)construir um Estado que permita ao cidadão o exercício pleno da cidadania, por intermédio de servidores do público. (MÁRCIO, 1996)

Percebe-se, então, que a resposta não é lógica, razoável, cartesiana. Há que se ter em mente, sempre, que qualquer decisão tomada no setor público tem grande componente/vertente social. As conseqüências são fortes. Não pode, por isso, ser 
baseada na vontade pessoal (modismos) ou privilegiar o viés puramente tecnocrático, vale dizer, o Estado não deve ser administrado de forma puramente empresarial, mas isso não significa que os conceitos da iniciativa privada devam ser exorcizados nas tomadas de decisão no setor público.

\section{2 - As mudanças e seus efeitos para os indivíduos}

Pode parecer clichê, lugar-comum, mas a grande verdade é que o mundo vive em constante transformação. Trata-se de processo extremamente dinâmico. As relações sociais acompanham esse processo. No ambiente de trabalho, o reflexo dessas mudanças é imediato. Valores, crenças e modos de agir são deixados de lado em função de modernas alternativas. Paradigmas são rompidos. O comportamento diante das mudanças varia de organização para organização, de pessoa para pessoa. Depende de diversos fatores. Inegável, porém, é a constatação dessa realidade no quotidiano das instituições.

Mendonça e Mendes (2002) afirmam que:

A sociedade contemporânea tem sido marcada por profundas mudanças sócio-organizacionais. As transformações no mundo do trabalho, a alta competitividade, a globalização dos mercados, os indicadores econômicos e a diminuição de postos de trabalho têm provocado impacto direto nas relações de trabalho. Conseqüentemente, as organizações têm precisado buscar alternativas de ajuste para se adequar às novas demandas. Esse processo conflituoso tem gerado experiências de injustiça e de sofrimento que levam os trabalhadores a se posicionar de diferentes maneiras, como, por exemplo, reagindo de maneira retaliatória. Nesse contexto conflituoso, as organizações se deparam com a necessidade de se ajustar às novas demandas de sobrevivência no mercado. Essa realidade impõe o desafio de adequação e de ajustes que muitas vezes requerem um conjunto de ações e decisões passíveis de ser percebidas pelos trabalhadores como injustas. Emergem, assim, questões merecedoras de investigação: em que medida a percepção dos trabalhadores de que as organizações são injustas gera sofrimento? A injustiça e o sofrimento no trabalho provocam reações retaliatórias? Quais as características das reações retaliatórias em contextos de injustiça e de sofrimento - positivas ou negativas? (MENDONÇA e MENDES, 2002, p. 143) 
As mudanças são implantadas, na maioria das vezes, verticalmente, vale dizer, são impostas pela administração superior. Os objetivos que as norteiam, administrativos ou organizacionais, nem sempre são comunicados à equipe ou previamente discutidos com os escalões inferiores (operacionais). O resultado é uma grande apreensão. Talvez o ambiente do trabalho - notadamente no caso da coordenadoria em estudo - tenha se modificado e acompanhado o avanço das tecnologias com mais velocidade do que a capacidade de adaptação dos servidores envolvidos no processo. As mudanças, velozes e inevitáveis, segundo alguns, conduzem os profissionais a uma tensão contínua, não só no ambiente de trabalho, como também na vida em geral, pois impossível se torna dissociar tais elementos.

Ballone (2005), orienta conforme transcrição a seguir:

Há, portanto, uma ampla área da vida moderna onde se misturam as demandas do trabalho e da vida cotidiana. A pessoa, além das habituais responsabilidades ocupacionais, além da alta competitividade exigida pelas empresas, além das necessidades de aprendizado constante, tem que lidar com os problemas normais da vida em sociedade, tais como a segurança social, a manutenção da família, as exigências culturais, etc. É bem possível que todos esses novos desafios superem os limites

E, enfatiza: adaptativos e conduzam ao estresse. (BALLONE, 2005)

Os tipos de desgastes aos quais as pessoas são submetidas nas relações com o trabalho são fatores determinantes de doenças. $O$ desgaste emocional é fator significativo na determinação de transtornos relacionados ao estresse, como é o caso das depressões, ansiedade patológica, pânico, fobias, doenças psicossomáticas, etc. Em geral, a pessoa com algum tipo de estresse ocupacional não responde à demanda do trabalho e geralmente se encontra irritável e deprimida. (BALLONE, 2005)

Dentre os agravantes do estresse no trabalho podemos citar a limitação que a sociedade submete as pessoas quanto às manifestações de suas angústias, frustrações e emoções. Somos impelidos a nos enquadrarmos. Não desejamos ser taxados de fracos. Por causa das normas e regras sociais, as pessoas acabam ficando prisioneiras do politicamente correto, obrigadas a aparentar um comportamento emocional ou motor incongruente com seus reais sentimentos. Poder-se-ia falar em uma espécie de "ditadura da aparência" sobre a essência.

No ambiente de trabalho, os estímulos causadores do estresse são muitos. 
A vivência diária no ambiente de trabalho e conhecimentos superficiais de Psicologia são suficientes para afirmar, com grande margem de segurança, que é possível experimentar ansiedade significativa diante de desentendimentos com colegas, da sobrecarga de trabalho, da corrida contra o tempo ou da insatisfação salarial. Geralmente, essas condições pioram quando não há clareza nas regras, normas e tarefas que deve desempenhar cada um dos trabalhadores, assim como os ambientes insalubres e a falta de ferramentas adequadas.

Os estudos de Ballone (2005) remetem à crença de que fatores internos relacionados ao serviço também contribuem para a pessoa manter-se estressada, como é o caso da sensação de insegurança no emprego (notadamente em tempos de crise econômico/financeira), sensação de insuficiência profissional, pressão para comprovação de eficiência, assédio moral em todas as suas formas e vertentes ou até mesmo a impressão continuada de se estar cometendo erros profissionais. Isso tudo sem contar os fatores que a pessoa traz consigo para o emprego, tais como conflitos, frustrações, problemas pessoais, etc.

\subsection{1 - Mudanças administrativas/gerenciais. Como? Por quê?}

A cada novo biênio, a organização pública em estudo passa por enormes mudanças estruturais e administrativas. O rodízio regimental na presidência do órgão traz consigo novas caras e novas formas de gerenciamento. Mudam-se focos e paradigmas. Novas teorias de administração são testadas. Imperam-se os modismos. Os novos dirigentes querem deixar sua marca. A cobrança por novas posturas é constante. As unidades têm sua importância hierárquica valorizada ou desvalorizada de acordo com a ideologia ocasionalmente predominante. As cobranças por respostas imediatas vão além da capacidade percebida pelo servidor, em função da exigüidade do tempo, o que pode ser considerado um fator importante para a eclosão do estresse patológico no trabalho. A sobrecarga de estímulos estressores é um estado no qual as exigências do ambiente excedem nossa capacidade de adaptação.

O espaço para a discussão, quando existe, não é suficiente para a participação de um número maior de servidores. "Não havendo espaço para a escuta, que pressupõe dúvida do que está posto, haverá um comprometimento da interpretação final dos resultados. O discurso oficial será tomado como verdade”. (MENDES, 2007) 
Acompanhando as mudanças na administração superior, normalmente mudamse os gerentes. Os critérios para a ocupação dos novos postos nem sempre são objetivos, transparentes e/ou previamente definidos. Além da necessária capacidade técnica, o critério de escolha político tem seu peso. Assim, a falta de estímulos para o crescimento profissional está presente, o que também pode resultar em estresse patológico. Nesses casos, a condição associada ao estresse costuma ser o tédio, a sensação de nulidade/inutilidade, a solidão e o isolamento.

Conforme o entendimento de Ballone (2005), as atividades medíocres no trabalho, aquelas destituídas de significação ou aquelas onde não se tem noção do porque se está fazendo, podem ser extremamente estressantes, além de altamente desmotivadoras. As tarefas altamente repetitivas ou desinteressantes também podem produzir estresse. O autor prega que situações de carência de solicitações ou a sensação de falta de significado para as coisas que fazemos costumam conduzir a uma sensação de impotência, de inutilidade, que enfraquece, humilha e reduz a auto-estima.

Quando se menciona - o que acontece com muita frequiência - a possibilidade de substituição do processo de produção de notas taquigráficas pelo processo mecânico - estenotipia - a sensação de insegurança daí resultante é muito grande. A esperança, perspectiva ou expectativa otimista é uma das motivações que mais aliviam as tensões do cotidiano. Saber, acreditar que amanhã será melhor que hoje, que mês que vem poderá ser melhor que este ou que no próximo ano as coisas serão melhores são sentimentos que minimizam a ansiedade e a frustração do cotidiano. Claro está, portanto, que na falta das boas perspectivas, ou, o que é pior, na presença de perspectivas pessimistas, a pessoa ficará totalmente à mercê dos efeitos ansiosos do cotidiano, sem esperanças de recompensas agradáveis. Há ambientes de trabalho onde o futuro se mostra continuamente duvidoso e sombrio.

\subsection{2 - Mudanças no ambiente físico de trabalho}

O conforto humano no trabalho deve ser sempre considerado em se tratando de estresse. O Comitê de Ergonomia do Superior Tribunal de Justiça desenvolveu, em 2007, um interessante estudo sobre as condições de trabalho naquele Órgão, notadamente na Secretaria dos Órgãos Julgadores, analisando as condições de trabalho naquela Unidade. O relatório final do referido Comitê concluiu que: 
Devemos sempre considerar o conforto térmico, acústico, as horas trabalhadas ininterruptamente, a exigência física, postural e outros elementos associados ao desempenho profissional. Ambientes hostis em termos de temperatura, umidade do ar e contacto com agentes agressivos à saúde fazem parte da exigência física a qual alguns trabalhadores estão submetidos. Daí a enorme importância do assessoramento técnico da Medicina do Trabalho para prevenir estados de esgotamento. (Relatório do Comitê de Ergonomia do STJ)

E, analisando as formas de reação dos servidores ao ambiente de trabalho, o relatório mostra que "ambientes com ruído excessivo podem ser extremamente estressantes pela estimulação do Sistema Nervoso Simpático, provocando irritabilidade e diminuindo o poder de concentração". Dessa forma, o ruído pode ter um efeito físico e/ou psicológico, capazes de desencadear a reação de estresse. Este fator pode produzir alterações em funções fisiológicas essenciais, como é o caso do sistema cardiovascular e produzir irritação, além de variações bruscas no humor e, conseqüentemente, no rendimento no trabalho.

As necessidades de mudanças podem ser comparadas a um ciclo vicioso. $\mathrm{O}$ momento presente, notadamente considerando a crise econômico-financeira, está a exigir mudanças - de mentalidade, de atuação, enfim, de paradigmas. Essas mudanças trazem novos problemas. Esses problemas despertam novas soluções, as quais passam a exigir novas mudanças e assim por diante. As mudanças podem ser determinadas por uma nova direção, gerência, chefia ou devidas à nova orientação geral, o que, invariavelmente, pode gerar, inicialmente, muita insegurança. A adaptação à nova realidade normalmente vem acompanhada de muita tensão. Evidentemente que as pessoas naturalmente possuidoras de dificuldades adaptativas sofrerão mais. Abrir mão de métodos usuais para aprender ou aceitar novos métodos exige sempre uma participação emocional importante.

A adoção de modernidades tecnológicas está continuamente substituindo os sistemas por outros mais modernos e, quase sempre, operacionalmente mais complexos. Nessa situação, as pessoas são emocionalmente solicitadas a se adaptarem ao novo, mas o custo pode ser muito grande, pois toda mudança requer nova mentalidade, novos paradigmas. Sobre o assunto o ensinamento é no sentido de que:

As pessoas com instabilidade afetiva, traços marcantes de ansiedade ou previamente estressadas sofrem mais. Em relação às próprias mudanças, sofrerão mais as pessoas 
confrontadas com novas tecnologias ideologicamente diferentes das anteriores. (BALLONE, 2005)

A introdução massiva das tecnologias de informação (TI) e o advento em larga escala da informática nas organizações trouxeram à baila a expressão "sociedade do conhecimento" para designar o novo estágio de desenvolvimento em que se encontram.

É de se interrogar, porém, diante das crescentes e incessantes transformações sócio-organizacionais às quais todos estão submetidos, se a expressão "sociedade do comportamento" não seria mais adequada para definir as crescentes exigências impostas pelos contornos das novas dinâmicas organizacionais. Com efeito, a velocidade exponencial das mudanças e a necessária adaptação dos atores sociais e organizacionais levam a que os mesmos não possam evoluir apenas nas cada vez mais exigidas competências e conhecimentos técnicos, mas, essencialmente, nos comportamentais.

As idiossincrasias organizacionais de uma macroestrutura como a Administração Pública devem ser especialmente sensíveis a essa questão, uma vez que para que se possam alterar e modernizar os seus procedimentos, tradicionalmente ancorados em aspectos de caráter normativo e burocrático, importa, não só o recurso à implementação das novas tecnologias, sem dúvida, potenciais facilitadoras de uma nova forma de organização, mas, sobretudo, de novos comportamentos decorrentes da percepção de organizações, grupos $e$ indivíduos de que importa alterar modelos atitudinais/comportamentais em face de uma nova ordem organizacional. Só assim a realidade administrativa poderá acompanhar os novos, contextos políticos, sociais, econômicos e organizacionais que a enquadram. (MADUREIRA e RODRIGUES, 2006, p. 154)

Não se deve abandonar a idéia de que as mudanças são requeridas, impostas mesmo, mas não há, de forma geral, uma explicitação daquilo que se pretende mudar nem porque as mudanças estão acontecendo, e, tudo é feito conforme o adágio popular: "Manda quem pode e obedece quem tem juízo".

Os servidores públicos são portadores, diante de sua trajetória pessoal e profissional, de crenças, valores, expectativas, competências e visões de mundo e de vida em sociedade que fazem parte do seu conjunto. Impossível se torna a dissociação ou fragmentação de alguns desses valores. O ser humano é o conjunto.

Quando se fala de "mudança", é determinante que se entenda com rigor a terminologia que se está a utilizar. Não devemos nesta matéria esquecer que já no início da 
investigação sobre a teoria dos processos de mudança, Lewin (1965) admitia a existência de três fases ao longo de um processo de mudança: descongelamento, mudança e recongelamento. Mais recentemente, Schein (1987), tentando desenvolver o conteúdo de cada uma das fases propostas por Lewin, postulou que o descongelamento deveria funcionar como um mecanismo de remoção ou de destruição de crenças, valores, atitudes e comportamentos partilhados $e$ praticados pelos indivíduos até esse momento, através da apresentação de novos padrões e de novos estímulos comportamentais susceptíveis de desafiarem a solidez dos anteriores. (MADUREIRA e RODRIGUES 2006, p. 170)

Há que se ter em mente, então, que quando se exigem, quando se impõem mudanças bruscas, repentinas, verticais, pode ocorrer o desencadeamento de um processo de resistência, seja em nível individual ou coletivo, notadamente no contexto organizacional, motivado pela falta de segurança psicológica dos indivíduos, trabalhadores e/ou servidores, relativa ao momento vivido nas organizações, à perda de privilégios, às diversas formas de incertezas em relação ao futuro ou à perda da hegemonia das competências pela introdução de novas tecnologias às quais não dominam e sentem-se incapacitados para buscarem alternativas.

\section{3 - Psicodinâmica do Trabalho}

“(...) O elemento decisivo que faz o trabalho propender para o bem ou o mal, no plano moral e político, é o medo.

Não o medo em geral, mas o medo que se insinua na própria atividade do trabalho.

Seja quando uma atividade inspira medo, como no Exército, nas minas, na construção civil, onde o medo estrutura o próprio trabalho; seja quando a atividade é poluída pelo medo, como na ameaça de precarização utilizada,

larga manu, nos grandes estabelecimentos."

(DEJOURS, 1999, p.141)

Atribui-se a Dejours (2007) a abordagem científica do conceito de Psicodinâmica do Trabalho. Isso se deu com a publicação na França de Travail: usure 
mentale. Essai de psychopathologie du travail, em 1980, traduzido no Brasil como A Loucura do Trabalho: estudos de psicopatologia do trabalho, em 1987.

O conceito de Psicodinâmica do Trabalho veio substituir o de psicopatologia do trabalho, já que aquele privilegia o estudo da normalidade sobre o da patologia, enquanto que "a psicodinâmica fornece as bases para a psicopatologia" conforme se vê nas palavras de Dejours (2007) abaixo:

É a partir da análise das situações saudáveis, caracterizadas pelas mediações bem-sucedidas diante das contradições da organização do trabalho, provocadoras de sofrimento, que se compreendem as patologias, uma vez que as falhas dessas medições impedem a mobilização subjetiva e levam à patologização das defesas.(DEJOURS, 2007)

Em sua primeira fase, a Psicodinâmica do Trabalho busca compreender como determinados trabalhadores, mesmo em ambientes hostis, sujeitos a condições não ideais, conseguem manter o equilíbrio psíquico.

É objeto da Psicodinâmica do Trabalho o estudo das relações dinâmicas entre organização do trabalho $e$ processos de subjetivação, que se manifestam nas vivências de prazer-sofrimento, nas estratégias de ação para mediar contradições da organização do trabalho, nas patologias sociais, na saúde e no adoecimento. (MENDES, 2007)

Na fase seguinte, a Psicodinâmica do Trabalho analisa as relações de prazersofrimento como dialéticas, dicotômicas e inerentes a todo o contexto de trabalho. Há um enfoque também nas estratégias utilizadas pelos trabalhadores diante das imposições da organização do trabalho para manter a saúde, evitar o adoecimento e assegurar a produtividade. Surgem, aqui, as ações coletivas. O trabalhador, para transformar o sofrimento no trabalho em uma atividade prazerosa, necessita de maior liberdade para agir, precisa usar sua inteligência prática e formular ações em grupo capazes de promover vivências de prazer.

O enfoque da psicodinâmica, então, volta-se para a análise do ambiente real de trabalho como o lugar de construção da identidade do trabalhador. Busca-se transformar o sofrimento, e não eliminá-lo. Ressalta-se que o objetivo não é transformar o sofrimento do indivíduo isoladamente, mas o da coletividade. As intervenções terapêuticas visam à organização do trabalho à qual os indivíduos estejam submetidos. 
A terceira fase, atualíssima, iniciada no final da década de 1990 é a consolidação da Psicodinâmica do Trabalho como abordagem científica capaz de explicar os efeitos do ambiente, das vivências de trabalho nos processos de subjetivação, ensimesmamento e na saúde dos trabalhadores.

Aqui, já não se direciona a atenção para as vivências de prazer-sofrimento, mas para o modo como os trabalhadores agem diante das turbulências. As estratégias individuais e coletivas de defesa e as novas formas de organização, cooperação e engajamento dos trabalhadores, assim como a banalização do sofrimento e das injustiças, a violência no trabalho, o assédio moral e as constantes ameaças de exclusão, além dos distúrbios laborais, como depressão, alcoolismo e suicídio, numa inversão da perspectiva teórica inicial, passam, então, a ser objeto de estudo da Psicodinâmica do Trabalho.

O trabalho pode ser um elemento de inserção social e de auto-realização. Pode, por outro lado, tornar-se fonte de sofrimento, de alienação e de dominação social, que, em suas novas formas de apresentação, são mais sofisticados e de difícil identificação. As sábias palavras abaixo corroboram esse pensamento:

A lógica da racionalidade econômica, principal fonte inspiradora para as novas formas de organização do trabalho, que, por sua vez, criam novas formas de subjetivação, de sofrimento, de patologias e de possibilidades de reação e ação dos trabalhadores tem gerado inúmeras mudanças no mundo do trabalho. (DEJOURS, 2007)

As novas formas de ameaças são invisíveis. Vão da perda individual do emprego à desestabilização coletiva do trabalho. Presentes estão também o assédio moral e a avaliação de desempenho (avaliação por competências) com caráter intimidatório, coercitivo e punitivo. Do ponto de vista ideal, entende-se que a vivência no trabalho deve constituir-se de fonte de prazer (identidade, realização reconhecimento e liberdade). Sendo assim, o trabalhador se torna sujeito da ação e cria estratégias que fazem com que ele domine o trabalho, e não seja dominado por ele.

Para se estudar as vivências de prazer-sofrimento no trabalho deve-se perpassar as condições físicas. É necessário avaliar as relações de poder e hierarquia. Quando o entendimento entre o sujeito e a realidade imposta pela organização do trabalho não é mais possível, advém o sofrimento. Os trabalhadores, diante da 
impossibilidade de transformação dessa realidade, organizam-se buscando estratégias individuais e/ou coletivas de defesa, na tentativa de subversão, valendo-se para tanto da inteligência prática, buscando alternativas para transformar o sofrimento em prazer ou alienam-se e "entregam os pontos". Como conseqüência, a qualidade e a produtividade são profundamente alteradas. Outros há, porém, que usam as diversidades impostas pela realidade como impulsionador do desempenho. As reações não são uniformes.

O ambiente de trabalho:

Expressa o lócus material, organizacional e social onde se operam a atividade de trabalho $e$ as estratégias individuais e coletivas de mediação utilizadas pelos trabalhadores na interação com a realidade de trabalho. (FERREIRA e MENDES, 2003)

As dimensões que compõem o Contexto de Produção de Bens e Serviços são: Organização do Trabalho; Condições de Trabalho e Relações Sociais de Trabalho. Ferreira e Mendes (2003) definem assim essas dimensões:

- Organização do Trabalho: Constituída pelos elementos prescritos (formal ou informalmente) que expressam as concepções e as práticas de gestão de pessoas e do trabalho presentes no lócus de produção e que balizam o seu funcionamento; (FERREIRA e MENDES, 2003)

- Condições de Trabalho: Composta pelos elementos estruturais que expressam as condições de trabalho presentes no lócus de produção e caracterizam sua infra-estrutura, apoio institucional e práticas administrativas; (FERREIRA e MENDES, 2003)

- Relações Sociais de Trabalho: Constituída pelos elementos interacionais que expressam as relações socioprofissionais de trabalho presentes no lócus de produção e que caracterizam sua dimensão social. (FERREIRA e MENDES, 2003)

As relações de prazer/sofrimento no trabalho devem ser observadas sobre todos esses ângulos, pois envolve diferentes atores em diferentes funções, com vivências, origens e valores diversos, por vezes diametralmente opostos, e há que se ter o necessário cuidado para que uns não se sobreponham hierarquicamente aos outros.

Ferreira e Mendes (2003) ensinam que o Custo Humano do Trabalho (CHT) pode ser entendido como:

$O$ que deve ser despendido pelos trabalhadores (individual e coletivamente) nas esferas física, cognitiva e 
afetiva vis-à-vis as contradições existentes no contexto de produção que obstaculizam (custo negativo) e desafiam (custo positivo) a inteligência dos trabalhadores. (FERREIRA e MENDES, 2003)

As exigências físicas são definidas pelos autores como "o custo corporal imposto aos trabalhadores pelas características do contexto de produção em termos de dispêndios fisiológico e biomecânico". Eles entendem que as exigências cognitivas "expressam o custo cognitivo imposto aos trabalhadores pelas características do contexto de produção, em termos de dispêndio mental", e por fim, que as exigências afetivas:

Expressam o custo afetivo imposto aos trabalhadores pelas características do contexto de produção, em termos de dispêndio emocional, pois o custo humano do trabalho abrange as propriedades humanas do pensar, do agir e do sentir que, por sua vez, caracterizam e traçam os perfis dos modos de ser e de viver dos trabalhadores nos contextos de produção. (FERREIRA, 2006)

As dimensões do Contexto da Produção de Bens e Serviços (CPBS) organização do trabalho, condições de trabalho e relações socioprofissionais configuram o custo humano do trabalho, uma vez que constroem as estratégias de mediações individuais e coletivas dos trabalhadores. Sempre que acontecem mudanças no ambiente de trabalho, sejam administrativas ou estruturais, muda-se o Contexto da Produção de Bens e Serviços (CPBS), com todas as suas consequências.

As vivências de bem-estar e mal-estar no trabalho, segundo Ferreira e Mendes (2003), são representações mentais relativas ao estado geral em contextos determinados e mediante condições determinadas. Nas representações de bem-estar, os trabalhadores expressam avaliações positivas sobre seu estado físico, psicológico e social relativos ao contexto de produção no qual se inserem. Já as representações de mal-estar significam avaliações negativas em relação a tais condições.

$N a$ circunstância de o sofrimento não ser ressignificado $e$ transformado em prazer, resta ao trabalhador, para manter sua integridade sociopsíquica, o uso de estratégias de defesa. Diante das novas formas de organização do 
trabalho, diferentes tipos de defesa, individuais $e$ coletivas, têm sido construídas pelos trabalhadores. São elas: cinismo, dissimulação, hiperatividade, desesperança de ser reconhecido, desprezo, danos aos subordinados, negação do risco inerente ao trabalho e distorção da comunicação. (MENDES, 2007)

O magistério de Dejours (2003) é taxativo no sentido de que os mecanismos de defesa, quando usados de forma exacerbada, podem levar à incapacidade de pensar, implicando na banalização das injustiças no ambiente de trabalho e na aceitação, por parte dos trabalhadores, de práticas contrárias a valores éticos que infringem sofrimento ao outro, passando a ser um modo de consentimento e banalização do mal e das injustiças.

Os principais aspectos que compõem as atitudes frente às mudanças são o ceticismo, o temor ou a aceitação. Quando essas mudanças são impostas, há, ainda, a perturbação frente ao inusitado, ao novo. Como as reações se dão de formas diferentes, os aspectos anteriormente citados podem estar mais de um ao mesmo tempo em determinadas pessoas ou grupos, o que pode fazer com que busquem uma maior aproximação, que culmina em "guetos" de resistência na unidade. A presença desses segmentos, dessas fragmentações pode ser um sinalizador de que alguma coisa vai mal. 


\section{3 - CONTEXTUALIZAÇÃO}

\section{1 - A Organização Pública Federal}

A organização pública federal objeto do nosso estudo pertence aos quadros do Poder Judiciário Federal e situa-se em Brasília, com jurisdição em todo o território nacional. É a responsável por apreciar, em grau de recurso, causas oriundas de todo o País, em todas as vertentes jurisdicionais não-especializadas, e atua na uniformização da interpretação da lei federal, além de analisar causas infraconstitucionais advindas de todos os estados. Sua competência, prevista constitucionalmente, estabelece os processos que têm início na própria Corte (originários) e os casos em que age como órgão de revisão (Corte recursal).

Seu quadro funcional é formado por servidores efetivos (nível médio e superior), admitidos por concurso, servidores requisitados de outros órgãos da Administração Pública, além de servidores terceirizados e estagiários.

\section{2 - Taquigrafia}

Taquigrafia ou estenografia $($ do grego taqui $=$ rápido e grafia $=$ escrita), segundo a enciclopédia Wikipédia (2008) é:

Um termo geral que define todo método abreviado ou simbólico de escrita, com o objetivo de melhorar a velocidade da escrita ou a brevidade, em comparação a um método padrão de escrita. A diferença entre taquigrafia e estenotipia é que a taquigrafia é feita a mão, geralmente usando lápis ou caneta; já a estenotipia utiliza máquinas próprias na composição dos taquigramas. Os sistemas típicos da taquigrafia fornecem símbolos ou abreviaturas para as palavras e as frases comuns, o que permite que alguém, bem treinado no sistema, escreva tão rapidamente que possa acompanhar as falas de um discurso. (Wikipédia-2008)

O primeiro registro taquigráfico de que se tem notícia data de 70 a.C. A taquigrafia judiciária remonta ao século I da Era Cristã. Nos tribunais gregos e romanos, 
os exceptores se encarregavam do registro taquigráfico de discursos, interrogatórios, debates e sentenças.

A enciclopédia Wikipédia (2008) informa que a taquigrafia surgiu como unidade administrativa na Assembléia Constituinte de 1823, de onde derivou para as Cortes de Justiça. Atualmente, há unidades de taquigrafia no Supremo Tribunal Federal, Superior Tribunal de Justiça, Tribunal Superior do Trabalho, Tribunal Superior Eleitoral, Tribunais Regionais Federais, Tribunais de Justiça dos Estados e do Distrito Federal, Tribunais Regionais Eleitorais, Tribunais Regionais do Trabalho e nas casas legislativas de todo o País, nos âmbitos federal, estadual e municipal.

A coordenadoria de taquigrafia em estudo é vinculada a uma unidade cuja missão é dar apoio à atividade judicante, auxiliar no processamento e julgamento dos processos de competência originária e recursal do órgão do Poder Judiciário federal em estudo, prestar apoio aos advogados, proceder ao apanhamento taquigráfico nas sessões de julgamento e eventos realizados pelo órgão e pelos demais elementos julgadores a ele vinculados, expedir as comunicações oficiais, promover a execução judicial dos feitos de competência originária, publicar os acórdãos e decisões e cumprir mandados judiciais, oferecendo ao jurisdicionado uma prestação acessível, rápida e efetiva.

A ex-servidora e ex-taquigrafa do Senado Federal, Dalva Ribeiro Vianna, atualmente em gozo de aposentadoria define na transcrição abaixo, o seu conceito de Taquigrafia:

Taquigrafia é história, é ciência, é arte, é profissão. É história porque registra para a posteridade acontecimentos e palavras que iriam ficar perdidas para sempre; é ciência porque exige de seu praticante um conjunto de conhecimentos; é arte porque, para ser perfeitamente executada, faz-se mister uma série de conceitos; é profissão porque é uma atividade especializada, um modo de vida de quem se espera exercício preponderantemente técnico $e$ intelectual.(VIANNA, 2008)

\section{3 - Coordenadoria de Taquigrafia}

A coordenadoria de taquigrafia da referida organização é composta por 128 servidores: 97 taquígrafos; 15 servidores da área administrativa; 15 servidores técnicos 
em telecomunicação e eletricidade e um técnico operador de computador. Vinculada a uma unidade responsável por organizar o trâmite processual na organização, presta serviços diretamente às outras coordenadorias, além de atender aos gabinetes dos magistrados.

Antes das mudanças estruturais e administrativas objeto deste estudo, a coordenadoria de taquigrafia atuava apenas nas sessões de julgamento. Para tanto, os servidores utilizavam bloco de papel, lápis e máquina de datilografar. Todas as notas taquigráficas eram reproduzidas heliograficamente. Não havia a subdivisão em seções. O trabalho era entregue às coordenadorias e gabinetes de quatro a cinco dias após o julgamento. Administrativamente, a estrutura era bastante simplificada: uma diretora e duas chefes de seção. Uma cuidava da parte referente ao apanhamento e revisão das notas taquigráficas; à outra, competia todos os assuntos relacionados à gerência de pessoal (administrativos).

Após passar por profundas transformações estruturais e administrativas, além de uma mudança significativa no processo de produção das notas taquigráficas, algumas seções foram extintas; outras, criadas. Funções comissionadas (gratificações) deixaram de existir. Servidores que ocupavam cargos de chefia há muitos anos foram substituídos. Foi instituído o controle eletrônico de freqüência. Servidores que anteriormente atuavam cada dia em uma turma julgadora diferente foram fixados em turmas julgadoras específicas, com rodízio semestral, sob o argumento - não unânime de busca de qualidade e celeridade no processo de trabalho. Apenas supervisores e revisores continuaram fixos. O processo de produção de notas taquigráficas foi profundamente alterado com o advento de modernos recursos tecnológicos. A demanda de trabalho aumentou em função do aumento no número de processos julgados, resultado de um maior grau de conscientização da população sobre seus direitos. Além do aumento substantivo no número de processos julgados, a coordenadoria de taquigrafia foi instada a atuar em eventos de outros órgãos vinculados à organização.

E tudo isso, registre-se, com o mesmo número de servidores.

O espaço físico destinado à coordenadoria de taquigrafia foi diminuído. Algumas salas que eram utilizadas pela referida coordenadoria receberam outra destinação, resultado de políticas ocasionais de privilegiar este ou aquele segmento funcional. Servidores foram colocados em espaços reduzidos, sem divisão, com pouca privacidade e muito barulho. Além de tudo, há ainda a constante ameaça - em nosso entender inviável, registre-se - da implantação do processo de estenotipia (estenografia 
mecânica, por meio de estenótipo), o que, segundo alguns, tornaria dispensável o trabalho realizado pelos taquígrafos.

Atualmente, dentre suas funções, podemos destacar as de executar as atividades de produção de notas taquigráficas relativas às sessões de julgamento e de produção de textos referentes às solenidades e a outros eventos de interesse da organização.

A rotina de trabalha da coordenadoria de taquigrafia pode ser assim resumida:

- O taquígrafo-apanhador entra em uma das salas de julgamento e procede ao apanhamento das notas taquigráficas;

- O taquígrafo-apanhador retorna à coordenadoria, traduz os taquigramas e libera, em meio digital, as notas à fase da revisão;

- O taquígrafo-revisor, com auxílio do áudio, revisa as notas, verificando gramática, termos em latim, em língua estrangeira, citação de artigos, leis, etc.;

- O taquígrafo-revisor, após toda a verificação, libera as notas para a fase da supervisão;

- O taquígrafo-supervisor confere todos os dados relacionados aos processos julgados e procede à distribuição das notas para as unidades usuárias;

- O taquígrafo-supervisor libera as notas taquigráficas para as unidades e atende solicitações de conferência de áudios e degravações.

A seguir, o fluxograma do trabalho na coordenadoria em estudo: 


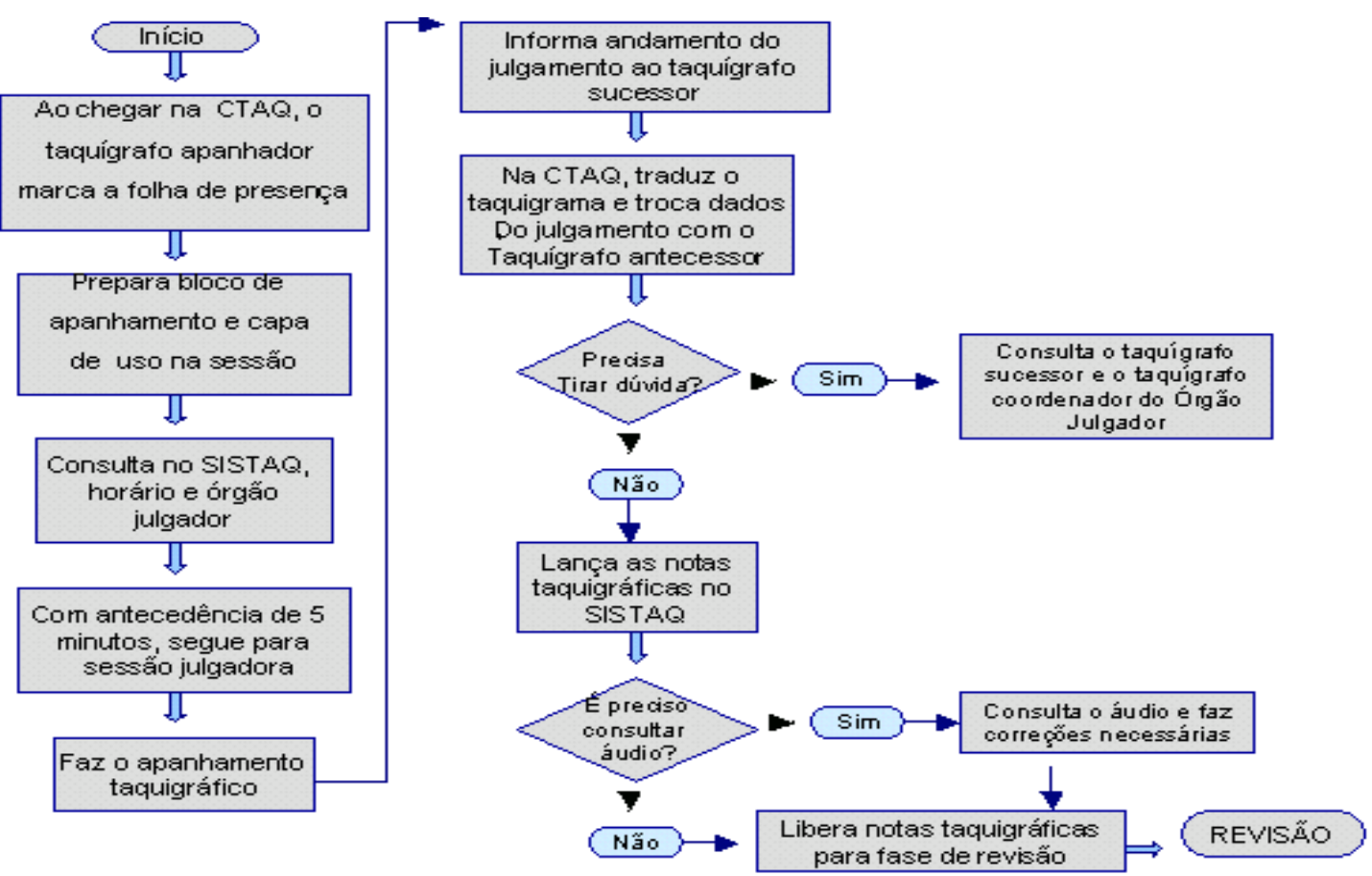

Fig. 1 - Fluxo de trabalho dos taquígrafos responsáveis pelo apanhamento

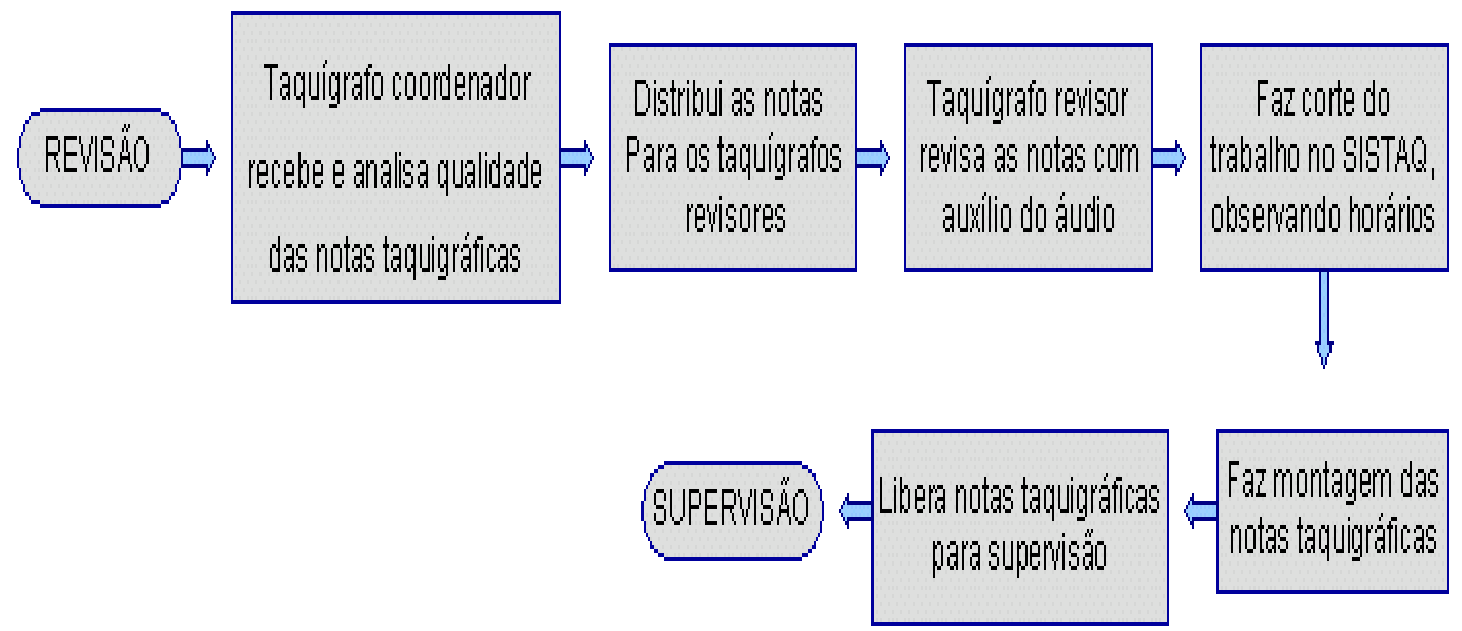

Fig. 2 - Fluxo de trabalho dos taquígrafos responsáveis pela revisão 


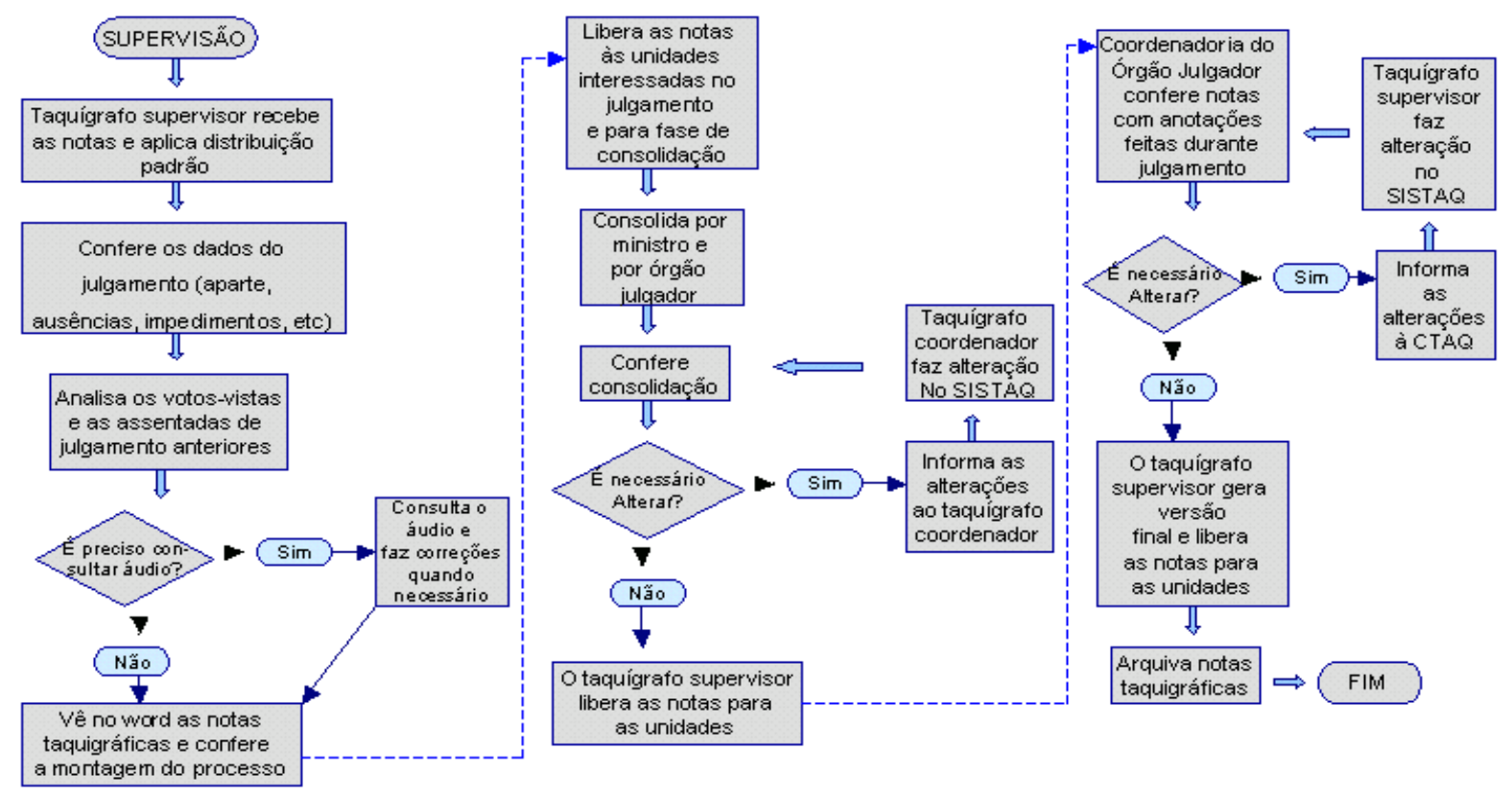

Fig. 3 - Fluxo de trabalho dos taquígrafos responsáveis pela supervisão. 


\section{4 - METODOLOGIA}

A pesquisa, de caráter qualitativo, deu-se por intermédio de uma entrevista aplicada aleatoriamente na coordenadoria de taquigrafia da organização em estudo.

Trata-se, conforme anteriormente descrito, de organização do Poder Judiciário federal, situada em Brasília, com jurisdição em todo o território nacional, cuja força de trabalho da coordenadoria de taquigrafia compõe-se de:

a) servidores terceirizados, que executam serviços de limpeza, vigilância, manutenção predial, copa e recepção;

b) estagiários que atuam no serviço de apoio administrativo;

c) servidores do quadro de pessoal, de nível médio e superior, com formações acadêmicas variadas, admitidos por concurso público, que atuam no apoio administrativo;

d) servidores do quadro de pessoal, de nível médio e superior, com formações acadêmicas variadas e com qualificação específica em taquigrafia, pertencentes à área de apoio especializado.

Participaram da pesquisa 14 (quatorze) servidores, analistas e técnicos judiciários, todos pertencentes ao quadro de pessoal da referida organização, entre 18 e 30 de novembro de 2008.

Entre os entrevistados do quadro de pessoal da referida organização, 02 (dois) servidores são pós-graduados, ocupam o cargo de analista judiciário e atuam na supervisão; 07 (sete) possuem curso superior completo (licenciatura ou bacharelado), ocupam o cargo de analista judiciário e atuam na revisão; e 05 (cinco) servidores possuem nível médio completo, ocupam o cargo de técnico judiciário e atuam no apanhamento taquigráfico. O tempo médio de trabalho na coordenadoria de taquigrafia é de 18 anos, sendo que dois servidores pertencem ao quadro há 03 (três) anos, e outros 02 (dois) há mais de 25 anos. 
No quadro a seguir, uma informação sintética dos entrevistados:

$\begin{array}{cccc}\text { Entrevistado } & \text { Cargo/Formação } & \text { Sexo } & \text { Tempo de trabalho } \\ 1 & \text { Nível Superior } & \text { F } & 14 \\ 2 & \text { Nível Superior } & \text { F } & 28 \\ 3 & \text { Nível Superior } & \text { F } & 3 \\ 4 & \text { Nível Médio } & \text { F } & 19 \\ 5 & \text { Nível Superior } & \text { F } & 18 \\ 6 & \text { Pós-Graduação } & \text { F } & 23 \\ 7 & \text { Nível Superior } & \text { F } & 3 \\ 8 & \text { Nível Superior } & \text { F } & 15 \\ 9 & \text { Nível Médio } & \text { F } & 19 \\ 10 & \text { Nível Médio } & \text { F } & 29 \\ 11 & \text { Pós-Graduação } & \text { F } & 24 \\ 12 & \text { Nível Superior } & \text { F } & 14 \\ 13 & \text { Nível Médio } & \text { M } & 21 \\ 14 & \text { Nível Médio } & \text { M } & 20\end{array}$

Fig. 4 - Quadro comparativo dos entrevistados

A predominância do sexo feminino entre os entrevistados não é proposital, mas infere-se tratar de uma característica da coordenadoria e/ou da própria profissão, pois menos de $10 \%$ (dez por cento) do quadro funcional é do sexo masculino.

\section{1 - Instrumento da coleta de dados}

A técnica utilizada foi a de entrevista individual em uma sala contígua ao departamento de supervisão, garantida a ampla liberdade nas respostas. A preocupação não foi - como não poderia ser - com a generalização ou a confirmação das expectativas, mas, sim, a de entender a dinâmica das relações/reações individuais e coletivas diante das mudanças ocorridas no contexto do trabalho. 
A escolha do instrumento se deu por entendermos que dessa forma os servidores teriam maior liberdade para expressarem seus sentimentos e expectativas. Alguns complementarem as respostas por meio eletrônico (e-mail). Mendes (2007) ensina que:

A entrevista usada nas pesquisas em clínica do trabalho, no referencial da psicodinâmica, prioriza a escuta como uma premissa básica. O pesquisador deve estar livre para escutar o que está fora de sua expectativa. As hipóteses devem acompanhar as questões, as quais não devem seguir um roteiro ritualístico. (MENDES, 2007)

A autora define a entrevista como:

Uma técnica para coletar dados, centrada na relação pesquisadores-pesquisados e na fala-escuta-fala dos conteúdos manifestos e latentes, sobre a organização do trabalho, as vivências de prazer-sofrimento, as mediações, e os processos de subjetivação e de saúde-adoecimento. (MENDES, 2007)

Consubstanciado nesse entendimento, buscou-se, por intermédio de uma entrevista semi-estruturada (anexo I), após validação pelo Professor-Orientador, compreender as relações de prazer e sofrimento no trabalho diante das mudanças. A pesquisa foi realizada com autorização da coordenadora de taquigrafia e foram feitas pessoalmente pelo pesquisador, tendo sido esclarecido previamente seu objetivo e garantido legalmente o sigilo. Quatro entrevistados preferiram responder por meio eletrônico (questionário), alegando que assim se sentiriam mais à vontade, o que foi aceito, desde que se comprometessem a complementar as respostas julgadas necessárias.

Tal exigência deve-se ao fato do questionário ser comumente confundido com a entrevista. Para Mendes (2007), tecnicamente, porém, o questionário é uma forma de investigação composta por um número mais ou menos elevado de questões apresentadas por escrito a pessoas quando se tem por objetivo propiciar determinado conhecimento ao pesquisador, mas as questões são prontas, "engessadas", diferenciando-se da entrevista, pois nessa as perguntas e respostas são feitas oralmente.

Assim, um questionário é um instrumento de investigação que visa recolher informações baseando-se, geralmente, na inquisição de um grupo representativo da população em estudo. É distribuída uma série de questões que abrangem um tema de interesse para os investigadores, não havendo interação direta entre estes e os inquiridos. 
Uma das vantagens do questionário em relação à entrevista é não expor os pesquisados à influência direta do pesquisador, além de permitir que as pessoas o respondam no momento que lhes parecer mais apropriado, tendo por desvantagem o "engessamento" das questões/perguntas, ou a restrição à liberdade do pesquisador.

Neste trabalho, posteriormente, foi feita uma complementação das respostas pelo seu autor. Foram feitas observações e oitivas informais de alguns servidores sobre o tema na busca de melhor compreensão dos sentimentos, crenças, atitudes, valores e motivações dos servidores diante das mudanças ocorridas. Além disso, ressalta-se a preocupação de melhor compreender a história individual dos entrevistados e as diferentes relações entre os diversos segmentos, com vistas ao encontro de um resultado bem próximo da realidade. 


\section{5 - PRAZER E SOFRIMENTO NO TRABALHO}

Serão demonstrados a seguir, os resultados obtidos por intermédio das entrevistas e questionários. Pretende-se que esses resultados retratem o ponto de vista dos servidores sobre as relações de prazer/sofrimento no trabalho em face das mudanças ocorridas na referida coordenadoria. Uma pesquisa bem estruturada deve permitir que, de posse das ferramentas apropriadas, se chegue, com tempo hábil e com energia, à exploração dos dados, o que nem sempre acontece. Além disso, "não pode haver equívoco: para se obter algo bom nos dados, deve-se conhecê-los a fundo e dedicar tempo a essa tarefa". (FREITAS, 2000)

Para uma melhor compreensão, torna-se necessário um desmembramento dos resultados em núcleos de sentidos operacionalizados a partir do agrupamento das respostas.

Deve se considerar a rede de significados revelados no conteúdo dos núcleos, que têm expressão em particularidades da linguagem, como, por exemplo, as conjunções (mas, no entanto, embora), os paradoxos, as metáforas, os chistes, entre outras figuras de linguagem, que fazem parte do núcleo de sentido e lhe dão consistência. (MENDES, 2007).

É preciso agrupá-los pela força dos temas mais recorrentes, que darão consistência aos núcleos, o que não impede de considerarmos, por razões óbvias, respostas com conteúdos fortes, mesmo que únicas, solitárias, pois contribuirão para uma melhor compreensão das relações de prazer/sofrimento no trabalho no âmbito da coordenadoria pesquisada.

\section{1 - Significado do trabalho}

Pelas respostas há que se interpretar o trabalho como de extrema importância como não poderia deixar de ser - na vida dos entrevistados, tanto do ponto de vista material (sobrevivência) quanto sob o ângulo da realização profissional. Percebe-se também uma preocupação com o alcance, a dimensão social das tarefas executadas, numa visão holística, maior do que apenas uma tarefa rotineira e cansativa. 
Quando indagados sobre o que lhes vinha à mente quando ouviam a palavra trabalho obtivemos respostas como:

Salário, dignidade, qualidade de vida, crescimento, sustento, filhos. (Entrevistado $\mathrm{n}^{\circ} 6$ )

Na função horizontal, o ser humano utiliza o trabalho como meio de subsistência pelo qual obtém o seu alimento, sua segurança e seu bem estar. É por meio dessa função que o indivíduo modifica o meio, transforma o habitat e cria condições de conforto para si e para seus familiares. Na função vertical, o trabalho faz com que o ser humano desenvolva sua capacidade de pensar, ampliando sua inteligência, bem como aperfeiçoando suas relações sociais e transformando-se interiormente. (Entrevistado $\left.\mathrm{n}^{\mathrm{o}} 11\right)$

Quando ouço a palavra trabalho, vêm-me à mente valores como independência, prazer, autonomia, felicidade, enfim, toda sorte de realização (Entrevistado $\mathrm{n}^{\circ} 13$ ).

Percebe-se que independência, autonomia financeira e subsistência estão presentes em quase todas as respostas. Observa-se também a preocupação com as relações sociais e com o crescimento profissional. O trabalho adquire, assim, sentido ímpar na vida dos participantes da pesquisa.

Questionados sobre os sentimentos em relação ao seu trabalho, as opiniões tomam rumos diversos. Há satisfação, orgulho, gratidão e vitória por terem um trabalho, por terem sido aprovados em um concurso público, mas transparece sentimentos de incerteza e algum grau de insatisfação, conforme se pode depreender dos trechos seguintes:

Satisfação. Minha vida profissional é como um complemento da minha vida privada. É o local onde, em troca da atividade que exerço, recebo remuneração para ter o conforto e a tranqüilidade que tenho. (Entrevistado $\mathrm{n}^{\circ} 01$ )

Sentimento de vitória por ter investido em estudo, passado em um concurso e alcançado meu objetivo. Sentimento de que ainda tenho muito a aprender. Sentimento de que as coisas poderiam funcionar melhor e que eu posso contribuir para isso”. (Entrevistado n ${ }^{\circ} 02$ ). 
É um misto de satisfação e desânimo. Satisfação, porque é uma atividade que tem horário flexível e que me dá tempo para cuidar das questões pessoais e profissionais. É uma atividade que me deixa mais independente. Não dependo de um chefe para saber o que tenho para fazer no dia. Desânimo, porque o tempo passa e os erros de administração de pessoal e de trabalho se repete. (Entrevistado $n^{\circ} 03$ )

Penso no desgaste físico e emocional. Meu local de trabalho é sinônimo de barulho, estresse. Por outro lado, o relacionamento pessoal é algo interessante. Somos um grupo grande, heterogêneo, mas que se assemelha na adversidade. (Entrevistado $\mathrm{n}^{\mathrm{o}} 13$ )

Nota-se que há uma predisposição à aceitação da realidade, muito embora isso não signifique conformismo. A capacidade de lutar e a disposição para discutir as transformações, contudo, encontra forte resistência na realidade sócio-econômica.

\section{2 - Relações de Prazer e Sofrimento no Trabalho}

As relações de prazer e sofrimento no trabalho são inerentes aos ambientes em que o mesmo se desenvolve. Ninguém está imune. Por outro lado, nenhuma instituição consegue ser totalmente cartesiana, retilínea, uníssona, conjugando apenas prazer ou apenas sofrimento. Oscila-se entre os dois pontos. É questão de momento, ocasião.

Para Dejours (2007), haveria uma tendência em crer que o sofrimento no trabalho é atenuado com a implantação das modernas tecnologias e que isso reduziria as tarefas repetitivas, mecânicas, automáticas e aumentaria o tempo para o prazer. Na afirmativa transcrita a seguir, fica claro o seu pensamento:

Querem nos fazer acreditar, ou tendemos a acreditar espontaneamente, que o sofrimento no trabalho foi bastante atenuado ou mesmo completamente eliminado pela mecanização e a robotização, que teriam abolido as obrigações mecânicas, as tarefas de manutenção e a relação direta com a matéria que caracterizavam as atividades industriais. Além de transformar braçais "cheirando a suor" em operadores de mãos limpas, elas tenderiam a transmutar operários em empregados e a livrar Pele de Asno de seu traje malcheiroso para 
propiciar-lhe um destino de princesa de vestido prateado. (DEJOURS, 2007)

Observa-se que a realidade se dá de forma distinta. As relações de prazer e sofrimento no trabalho são características das instituições. Há o sofrimento dos que temem não estar à altura das exigências e/ou das imposições das organizações diante da nova realidade, assim como há prazer daqueles que se sentem satisfeitos por ter um trabalho ou por pertencer a uma determinada organização. Neste estudo, isso ficou evidente nas respostas dos entrevistados sobre como enfrentam o dia-a-dia no trabalho. A seguir, alguns fragmentos dessas respostas:

"Como sou uma pessoa com muita iniciativa, confesso que preciso ter um pouco de paciência para não ir atropelando as coisas e resolvendo os problemas à minha maneira." (Entrevistado $\mathrm{n}^{\mathrm{O}} 02$ )

"Não preciso enfrentá-lo, porque o ambiente de trabalho é bom e as atividades são exercidas quase que de forma autônoma”. (Entrevistado $\mathrm{n}^{\circ} 10$ )

Além de tentar cumprir minhas obrigações de forma adequada, procuro um sentido maior do que apenas um meio de sobrevivência; procuro, também, utilizar o trabalho como meio de tornar-me um elemento útil na sociedade, adquirindo, dessa forma, o aprimoramento espiritual como ser em constante evolução. (Entrevistado $\left.\mathrm{n}^{\mathrm{o}} 11\right)$

Discorrendo acerca das modificações estruturais na coordenadoria e seus reflexos, um dos entrevistados asseverou:

Quando sofremos um ferimento no corpo, sentimos dor, mas há sempre um remédio para combatê-la. Porém, a dor advinda do constrangimento e do sofrimento - a dor na alma - é preciso ser reconhecida, sentida e enfrentada sem máscaras. Não vivê-la significa não resolvê-la e não eliminá-la. (Entrevistado $\mathrm{n}^{\mathrm{o}} 14$ )

Numa demonstração de clareza solar, de que os atos administrativos podem adquirir sentidos profundos e complexos nos atores do processo, com conseqüências nem sempre previsíveis. A resignação, a negação do sofrimento se faz presente, muito embora, internamente, os conflitos continuem existindo, conforme se vê do ensinamento abaixo transcrito: 
As estratégias defensivas são mecanismos de negação e racionalização da realidade de trabalho que faz sofrer. Caracteriza-se pela naturalização do sofrimento e das injustiças que os trabalhadores padecem e dos fracassos no trabalho como decorrentes da má-vontade ou da incapacidade humana. A racionalização compõe justificativas socialmente valorizadas para explicar situações desconfortáveis, desagradáveis e dolorosas que propiciam risco e impõem ritmo acelerado elou exigem elevados índices de desempenho e produtividade. (MENDES, 2003)

Isso ajuda a compreender a banalização do mal, do sofrimento e da injustiça social preconizados por Dejours. O sofrimento, na maioria das vezes invisível ou mesmo imperceptível, é banalizado, vale dizer, não se dá ao mesmo a devida importância. Há também a estratégia de ignorá-lo. A angústia, a insegurança ou o medo daí decorrentes manifestam-se em vivências de desvalorização dos servidores, o que acarreta em sensação de inutilidade e de desvalorização por parte dos mesmos. E esse estado de coisas vai gradativamente somatizando, vale dizer, transformando-se em doenças no trabalho, quando os trabalhadores já não conseguem mais se valer das estratégias individuais e/ou coletivas de enfrentamento.

\section{3 - Organização do trabalho}

A dimensão organização do trabalho tem importância capital nas relações de prazer e sofrimento no trabalho. Dimensão integrante do Contexto de Produção de Bens e Serviços (CPBS), classificação de Ferreira e Mendes (2003), compõe juntamente com as condições no trabalho e as relações sociais no trabalho a tríade classificatória da autora para explicar as dimensões laborais.

$\mathrm{Na}$ coordenadoria em estudo, a organização do trabalho foi bastante modificada. O processo de produção de notas taquigráficas passou por profundas alterações, desde a informatização do trânsito do trabalho (entre coordenadoria e destinatários) até o controle eletrônico de freqüência. Os servidores tiveram que se adequar. A nova organização do trabalho não é unanimidade, mas é uma realidade.

Instados a avaliar as condições atuais de trabalho (ambiente, recursos materiais, carga horária, salário, etc.), obteve-se respostas extremamente interessantes, dentre as quais destacamos: 
$O$ ambiente poderia ser melhor, mais amigável, mais unido, menos frio. $O$ salário é justo se compararmos com outras profissões. Com relação aos equipamentos, poderiam ser melhores: cada taquígrafo deveria ter a sua própria capa, os fones de ouvidos poderiam ser mais modernos, o sistema de informática poderia ser melhor, mais prático. Cabines individuais e com isolamento acústico melhorariam muito a qualidade do nosso ambiente de trabalho. (Entrevistado $\mathrm{n}^{\circ} 02$ )

São bons, mas poderiam ser melhores. A sala abarrotada de gente, fazendo muito barulho, interfere na capacidade de raciocinar. $O$ trabalho exige um alto nivel de concentração. Os supervisores ficam muito afastados. Sempre que temos alguma dúvida, temos que nos deslocar até os mesmos. Isso atrasa a entrega do trabalho, o que gera desconfiança em relação a nossa capacidade. (Entrevistado $\mathrm{n}^{\mathrm{o}}$ 06)

$\mathrm{Li}$, não me lembro onde, mas concordo em gênero, número e grau, que o clima não é determinado nem pela pessoa, nem pela instituição, nem pela chefia. A receita para fomentar um bom ambiente para trabalhar vem de algo que está no meio: o caráter dessas relações. Cada um é responsável pelo seu pedaço, com o tamanho da influência que tem. Mas é claro que a responsabilidade maior sobre o clima e a satisfação das pessoas está nas mãos dos gestores, que são os elementos de interação nessa cadeia. (Entrevistado $\mathrm{n}^{\circ} 12$ )

Infere-se que há um alto grau de conscientização em relação às condições de trabalho e atribui-se uma grande parcela de responsabilidade aos gestores. Esses, por seu turno, nem sempre dispõem dos conhecimentos necessários ou mesmo de poderes para atuarem de forma a modificar a estrutura organizacional.

\section{4 - Somatização}

"Toda enfermidade é intencional". Com essa frase, Sigmund Freud quis dizer que, de uma forma ou de outra, as pessoas adquirem ganhos secundários quando manifestam alguma doença. Esse é o caso das doenças psicossomáticas, vale dizer, de fundo emocional, que atingem um terço da população mundial. 
Doenças psicossomáticas são manifestações orgânicas que podem ser provocadas ou cujos sintomas podem ser agravados por problemas mentais ou emocionais. É um processo pelo qual a pessoa "transfere" para o organismo a carga emocional decorrente de algum problema que está vivendo. Isso desencadeia processos no organismo, gerando o estresse que, em longo prazo, provoca o aparecimento de doenças. A somatização corresponde a uma tendência de experimentar e de comunicar distúrbios e sintomas somáticos não explicados pelos achados patológicos, atribuí-los a doenças físicas e procurar ajuda médica.

Relatório do comitê de ergonomia do órgão objeto desta pesquisa, baseado em dados da secretaria de serviços integrados da saúde, aponta que entre julho de 2006 e julho de 2007 houve 259 dias úteis de trabalho, sendo que na coordenadoria pesquisada foram constatados 1221 dias de afastamento, distribuídos em 127 tipos de doenças assim divididos:

- 186 dias devidos a entorses, fraturas, contusões e luxações ósteo-musculares;

- 55 dias devido a doenças do aparelho respiratório;

- 109 dias por outros comprometimentos ósteomusculares e de tecidos moles;

- 364 dias em virtude de convalescença, sendo 141 dias em razão de convalescença pós-cirúrgica e 51 dias relativos a pessoas em boa saúde acompanhando pessoas doentes.

Questionados sobre a interferência do trabalho em seu comportamento e em sua saúde, os entrevistados assim responderam:

Por ser um trabalho que exige muita concentração, tenho me sentido mais tensa, o que faz com que eu sinta, freqüentemente, dores nas costas. $O$ fato de ficar muito tempo sentada também contribui. $O$ uso prolongado do fone de ouvido tem me causado dores de cabeça. (Entrevistado $\mathrm{n}^{\mathrm{o}}$ 02)

Sempre que há conflitos não resolvidos não há disposição para uma boa interação. Tenho dor de cabeça, dor na lombar e desânimo. (Entrevistado $n^{\circ}$ 03)

O trabalho exige um alto nível de concentração, agilidade e presteza, pois requer eficiência e eficácia, cumprimento rígido de prazos e horários. Isso acelera o meu metabolismo por inteiro, podendo gerar problemas físicos e psicológicos. (Entrevistado $\mathrm{n}^{\mathrm{o}} 06$ ) 
Trabalhar num setor com um quadro grande de servidores não é fácil, pois, momento a momento, surgem problemas pessoais. Por mais que tente não se envolver, isso leva, sim, a uma mudança de comportamento: de um lado, o entusiasmo; de outro, o desapontamento. Realmente, o custo humano para a realização do trabalho, no momento atual, está elevado. Creio que isso ocorra pelo fato de haver um reduzido quadro para melhor distribuir as atividades. (Entrevistado $\mathrm{n}^{\circ} 12$ )

Sempre que me sinto abalada psicologicamente, adoto o afastamento temporário para tentar entender o porquê da minha insatisfação, da minha tristeza. Não deixo de falar com os colegas, mas mantenho certa distância. Como alternativa, busco a ajuda de um psicólogo. (Entrevistado $\mathrm{n}^{\mathrm{o}} 13$ )

Pode-se notar que a dinâmica do trabalho interfere no comportamento e na saúde dos servidores, mas os números constantes no relatório do comitê de ergonomia necessitariam de uma análise estatística mais completa, detalhada, profunda para que pudéssemos estabelecer um nexo causal entre os tipos de doenças e a dinâmica, o contexto do trabalho após as mudanças, mas merece registro a quantidade de dias de afastamento e suas conseqüências, como, por exemplo, a sobrecarga de trabalho para os servidores remanescentes.

As respostas dos entrevistados revelam que a dinâmica de trabalho na referida coordenadoria exige um alto nível de concentração, o que acarreta em estresse e tensão, desembocando em problemas físicos e psicológicos. Percebe-se também a presença de conflitos em função do grande número de servidores na mesma sala, o que eleva o custo humano para a realização do trabalho com todas as suas consequiências. As reações vão desde o isolamento, quando o Entrevistado no 13 diz que "sempre que me sinto abalada psicologicamente, adoto o afastamento", até o processo de aceleração do metabolismo verbalizado pelo Entrevistado $\mathrm{n}^{\circ} 06$ que assevera que "isso acelera o meu metabolismo por inteiro, podendo gerar problemas físicos e psicológicos”.

Diante disso, percebe-se que as somatizações são responsáveis por um número alto de licenças médicas, gerando importantes gastos para o sistema de saúde e incorrendo em sofrimento para os envolvidos.

\section{5 - A influência das mudanças}


Referindo-se especificamente ao conjunto de mudanças pelas quais passou a coordenadoria objeto de nossa pesquisa, perguntamos sobre as condições de trabalho antes e após o advento das mudanças, isto é, queríamos saber se antes o trabalho no local era melhor ou pior. Como era de se esperar, em virtude das diferenças nas análises, não houve unanimidade num ou noutro sentido. Destacam-se a seguir, algumas manifestações:

Quando entrei, havia muito menos processos, as sessões terminavam mais cedo. Isso é sinal de que era melhor. Trabalhava-se menos e sob bem menos pressão. Mas hoje, com uma quantidade maior de processos e de discussões de novas teses, mesmo com o trabalho tendo aumentado sensivelmente, podemos ter certa garantia de que o nosso serviço é mais necessário a cada dia que passa. (Entrevistado $\mathrm{n}^{\mathrm{o}}$ 01)

Merece realce a resposta do Entrevistado $n^{\circ}$ 02, que estabeleceu uma relação curiosa entre a forma de trabalho (manual $\mathrm{x}$ informatizada) e as relações pessoais reconhecimento - e estabeleceu um paralelo, ainda que implicitamente, sobre a forma antiga e a atual de relacionamento entre gerentes e servidores, chegando a ser benevolente com os erros da administração pretérita. Durante sua manifestação foi assinalado que:

Antigamente não tínhamos metade dos recursos tecnológicos que temos atualmente, que agilizam o trabalho e ajudam a diminuir distâncias, mas era muito melhor, porque tínhamos mais reconhecimento de nossas capacidades. A pessoa escolhida para dirigir a coordenadoria - não sei se por pura simpatia, confiança ou se por avaliação - atendia mais às necessidades do trabalho e tinha muita aptidão para gerenciar pessoas. Ficou na direção durante doze anos. Os erros que essa chefia cometia não eram levados em conta devido aos inúmeros acertos de seus atos gerenciais. Eu tinha mais ânimo, era mais criativa, mais participativa e me sentia mais confiante. (Entrevistado $\mathrm{n}^{\circ} 02$ )

Dando seqüência às verbalizações sobre o ambiente de trabalho antes e após as mudanças, merecem destaque as seguintes respostas:

Era melhor, porque, mesmo não contando com muitos recursos tecnológicos, prevalecia o coleguismo, o companheirismo, o lado humano. Hoje é cada um por si. 
A disposição dos móveis - falta de espaço - também piorou muito." (Entrevistado $\mathrm{n}^{\mathrm{o}} 08$ )

Era bem melhor. Porque a chefia era mais acessivel; havia um maior reconhecimento do trabalho desenvolvido, um maior prestígio no desempenho das funções e, inclusive, gratificações para os taquígrafos. Os servidores tinham como sugerir mudanças para melhorar os trabalhos desenvolvidos. (Entrevistado $n^{\circ} 09$ )

Posso dizer que é algo relativo. Antes, não havia a tecnologia para nos dar o apoio que temos hoje; não havia um maior dinamismo para a distribuição das atividades; a realização do trabalho era feita de forma mais burocrática; a rádio corredor era muito ativa $e$ prejudicava as relações pessoais; além de outros fatores. Mas creio que as relações pessoais tenham ficado mais frias, talvez, pela distância do espaço físico. (Entrevistado $\mathrm{n}^{\mathrm{o}} 13$ )

"É bem visível a mudança que vem tendo a coordenadoria para melhor em todos os aspectos". (Entrevistado n 04)

Percebe-se das manifestações certo saudosismo lírico. Pode-se notar que o ritmo de trabalho aumentou em função de uma maior demanda de processos. Entende-se também que a implantação dos recursos tecnológicos e as mudanças estruturais conduziram a certo "isolamento" característico do modo de vida moderno, onde a comunicação é feita por meio eletrônico (e-mail) até com o colega da mesa ao lado, o que interferiu profundamente no relacionamento entre os servidores. Não se pode esquecer que a manipulação dos recursos tecnológicos é feita por seres humanos, isto é, diante de cada tela de computador, está uma pessoa com sentimentos, expectativas e sonhos. Podemos verificar que o modelo produtivo moderno atua significativamente na forma de agir no mundo do trabalho. Os processos sociais do dia-a-dia ficam desconectados do ambiente laboral. O modo de produção, da economia, dos números e o poder assumem o caráter de uma realidade intransponível, guiada por leis rígidas, imutáveis. Os servidores submetem-se a isso encarando como natural a submissão às leis do mercado e à burocracia estatal. A sensação de impotência, de que não há nada que possa ser feito, culmina em apatia e aceitamento.

\section{6 - Estratégias de enfrentamento}


Quando se é atingido, reage-se. É natural. No ambiente de trabalho, não poderia ser diferente. Se o senso de justiça é injuriado, é bastante provável que haverá luta para reorganizar as coisas, a não ser que já se esteja contaminado pelo processo de "banalização da injustiça social” preconizado por Dejours (2007) quando afirma que "essa insólita passividade coletiva estaria ligada à falta de perspectivas (econômica, social e política) alternativas”.

As reações nem sempre são semelhantes. Vão do "ensimesmamento", isolamento, aceitação, passividade, ao agrupamento daqueles que comungam do mesmo pensamento, organizando-se em estratégias coletivas de defesa e buscando alternativas. Até mesmo a aparente normalidade, onde resultados (números, tarefas) em termos de produtividade aparecem, não implica em ausência de sofrimento.

Na instituição pesquisada, os servidores foram questionados sobre o ambiente de trabalho e sobre as estratégias utilizadas pelos mesmos para lidar com as situações quotidianas, que poderiam acarretar em relações de prazer/sofrimento. A seguir, fragmentos das respostas:

Sempre procurei ser uma pessoa positiva e ter alegria, ao invés de ser depressiva e só ter pensamentos negativos. Procuro sempre ver o melhor lado de tudo o que acontece à minha volta. Ajo desse modo também no trabalho. Procuro tirar prazer e alegria daquilo que me tira da minha casa, do convívio da minha família. É assim que trabalho: com alegria, com prazer, com satisfação. (Entrevistado $\mathrm{n}^{\circ}$ 01)

Estimulamos o diálogo para que possamos ter sempre uma convivência harmoniosa. (Entrevistado ${ }^{\circ} 02$ )

Às vezes, questiono algumas coisas que não devem passar despercebidas, porque, assim, os problemas não tomam grandes proporções. (Entrevistado $\mathrm{n}^{\circ} 05$ )

Creio que a palavra mais adequada para o momento seja tentar. Tentar administrar melhor o tempo; tentar administrar minhas tarefas; tentar entender os problemas para encontrar a melhor solução; enfim, tentar buscar a tão falada "excelência”. (Entrevistado $\mathrm{n}^{\circ} 12$ )

Todas as vezes que me vejo em situações que me desagradam, como ter que enfrentar insegurança de chefe pela falta de preparo para lidar com gente, afasto-me para enxergar melhor a situação. Quando não consigo 
entender a situação e sinto-me confusa, procuro por ajuda profissional. (Entrevistado $\mathrm{n}^{\mathrm{o}} 13$ )

Existem aqueles que buscam aumentar o ritmo de trabalho, talvez movidos pelo pensamento de que o problema pode estar consigo, numa forma de resignação, aceitação, submissão mesmo; outros, por seu turno, buscam o diálogo e a companhia de quem comunga do mesmo sentimento, além de buscarem apoio em atividades fora da organização e até mesmo a ajuda de profissionais qualificados.

Conforme anotado anteriormente, a média de tempo de trabalho dos entrevistados no órgão em estudo é de 18 anos. Diante das observações e análises sobre o processo de trabalho, oriundas de servidores com vasta experiência e amplo conhecimento sobre os mecanismos de funcionamento da organização, sobre os métodos de trabalho e sobre as mudanças estruturais e administrativas a que foram submetidos na coordenadoria, buscamos captar a impressão dos mesmos a respeito da organização do trabalho e o que, em sua ótica, deveria ser mudado para amenizar o sofrimento.

A seguir, algumas verbalizações:

A organização do trabalho ainda deixa a desejar. A comunicação ainda é falha. A rotina da revisão ainda é desconhecida para muitos, o que faz com que o nosso trabalho não seja valorizado. Os profissionais não são diferenciados. Precisamos definir regras e o papel de cada um. Os apanhadores precisam vivenciar a rotina da revisão. O feedback precisa se tornar regra para todos, afinal, não tenho como saber se meu trabalho está bom ou se necessita de modificações. O bom profissional precisar ser valorizado. Existe uma cultura na coordenadoria de que se eu fizer certo ou errado dá no mesmo, se eu não fizer, tem quem faça, de que tenho que fazer rápido para ir embora. Com isso, penso que estamos sempre passando a mão na cabeça desses que fazem errado ou não fazem. Isso precisa ser mudado urgente. (Entrevistado $\mathrm{n}^{\mathrm{o}} 02$ )

O Entrevistado $\mathrm{n}^{\circ} 03$ discorreu detalhadamente sobre sua visão de como deveria ser a organização do trabalho na coordenadoria. Dentre suas inúmeras contribuições, é importante destacar suas impressões sobre:

Divisão de trabalho: não há uma divisão de trabalho equilibrada. Um dia uns trabalham muito enquanto outros trabalham pouco. No dia em que um grupo trabalha muito corre o risco de cometer erros graves devido ao cansaço. Setor indefinido: entendo que um setor ou uma seção para existir tem que haver a necessidade da sua existência 
e tem que ter número estabelecido de funcionários de acordo com a necessidade do trabalho. Necessidade do trabalho: atende-se mais a vontade do chefe ocasional do que a necessidade do trabalho. Cargo de chefia: hoje temos pessoas que são chefes sem ter perfil para tanto. Isso gera problemas difíceis para os subordinados mais diretos administrarem, tendo, muitas vezes, que coordenar, orientar, delegar, porque o chefe diz não ter facilidade para argumentar. Não gosta de pensar na possibilidade de se indispor com um subordinado. $O$ subordinado direto desse chefe faz o seu trabalho de subordinado e também o do chefe. Escolher um funcionário para ser chefe porque é amigo e confiável é mais fácil, porém não é uma escolha eficaz. Conhecer os funcionários: criar meios de melhor conhecer os funcionários. Saber quais são os auditivos, os visuais e os auditivos-visuais e trabalhar com eles de acordo com essas características e com suas qualidades, aproveitando, assim, o que cada um tem de bom. (Entrevistado $\mathrm{n}^{\mathrm{o}} 03$ )

Prosseguindo no registro das idéias sobre as modificações que os entrevistados entendem necessárias, merecem realce as seguintes:

Após as mudanças, houve uma melhoria, mas ainda há muito a ser feito. Todos na mesma sala, o barulho infernal, a irresponsabilidade $e$ a falta de comprometimento de alguns, softwares obsoletos e falta de coleguismo interferem na produtividade e na qualidade do trabalho. Penso que se faz necessário um maior profissionalismo. (Entrevistado $\mathrm{n}^{\circ} 06$ )

A organização é satisfatória, pois alcança os resultados finas do nosso trabalho. Acho que se houvesse uma comunicação maior entre chefias e servidores o trabalho poderia sair bem melhor. A valorização do trabalho também é muito importante, e não apenas ressaltar os erros. Deveria haver critérios mais objetivos para a promoção de servidores para os cargos de chefia. (Entrevistado $n^{\circ}$ 09)

Verifico a necessidade de haver algumas normas expressas para que sejam cumpridas por todos e não haja desgaste pessoal com negociações. Creio, também, que há uma distribuição inadequada do trabalho: uns trabalham muito; outros trabalham pouco, e a coordenadoria é uma só.. (Entrevistado $\left.\mathrm{n}^{\mathrm{o}} 13\right)$ 
Percebe-se que as mudanças não solucionaram totalmente os problemas. Há insatisfação quanto à parte administrativa, à organização do trabalho e às falhas na comunicação. Alguns profissionais sentem-se injustiçados ou sobrecarregados. É recorrente a insatisfação com o método de divisão do trabalho. O critério de escolha dos chefes, dos gerentes, é colocado em dúvida.

Para finalizar, foi solicitado aos entrevistados que resumissem seu trabalho em duas palavras. As palavras prazer e a palavra satisfação foram citadas quatro vezes, seguidas de perto por realização, mencionada três vezes. A seguir, vieram as palavras renúncia e sofrimento, recebendo duas menções cada. Dentre as palavras citadas apenas uma vez, é pertinente destacar: individualismo, dignidade, incerteza, engenhosidade e nostalgia.

Não há, pelo menos por enquanto, uma política organizacional institucionalizada para amenizar os efeitos das vivências de sofrimento. Os servidores se organizaram em uma associação, que oferece certo apoio do ponto de vista de lazer e entretenimento, mas nada direcionado especificamente para o combate aos problemas advindos das relações de sofrimento no trabalho. 


\section{6 - CONSIDERAÇÕES FINAIS}

Este estudo representa uma tentativa de compreender as relações de prazer e sofrimento no trabalho no âmbito da coordenadoria de taquigrafia de um órgão do Poder Judiciário federal, foi motivado por um trabalho anterior deste autor, realizado sobre assédio moral, onde muitos dos servidores da citada coordenadoria, mais de $70 \%$ (setenta por cento), se diziam vítimas do processo.

Diante dos dados e esclarecimentos naquela oportunidade, ficou claro a existência um problema de conceituação, pois o assédio moral para ficar caracterizado necessita, principalmente, da exposição repetitiva e prolongada dos servidores a situações humilhantes e/ou constrangedoras, de forma intencional, durante a jornada de trabalho, o que não era o caso, mas ficou evidente, principalmente após algumas modificações estruturais e administrativas ocorridas na referida coordenadoria, a insatisfação generalizada, o que nos levou a pensar sobre o assunto.

Inicialmente, buscou-se analisar o trabalho no setor público à luz da reforma gerencial, pois o advento do neoliberalismo exigiu um servidor mais preparado, qualificado, competitivo, profissionalizado, além da busca pelo modelo gerencial utilizado na iniciativa privada, sem levar em conta as especificidades do setor público.

Assim, o processo de modernização exigiu mudanças profundas, trazendo conceitos como flexibilidade, eficiência, eficácia, racionalização, inovação, avaliação por competências, mensurações e descentralização, com enormes conseqüências, pois rompiam com paradigmas e requeriam em seu bojo severa mudança de mentalidade.

Paralelamente, foi necessário a analise das implicações das diferentes formas de mudanças na organização do trabalho e a ação/reação dos trabalhadores frente a essas mudanças.

O presente trabalho acadêmico autoriza o pensamento de que as relações de prazer no trabalho vivenciadas pelos servidores da coordenadoria pesquisada advêm principalmente da possibilidade de realização material e profissional e da estabilidade oferecida pelo setor público, além de certo orgulho por atuarem em uma instituição que goza de boa reputação perante a sociedade e que atua no sentido de contribuir para que o Poder Judiciário seja o guardião das garantias constitucionais e do Estado democrático de direito, condições indispensáveis para uma convivência harmoniosa, sob a égide do respeito às leis. 
Por esse ângulo pode-se concluir que o serviço público, apesar de todas as mazelas, ainda é uma alternativa interessante.

Percebe-se também certa resignação, isto é, uma aceitação das coisas. Os servidores sentem-se impossibilitados, incapacitados mesmo de agirem no sentido de operacionalizar as necessárias transformações e aquietam-se passivamente diante das modificações que lhe são impostas.

Quanto às relações de sofrimento vivenciadas pelos participantes da pesquisa, as contribuições são no sentido de que grande parte é oriunda da organização do trabalho na referida unidade, além da forma como foram efetivadas as mudanças estruturais e administrativas.

Parte significativa dos participantes relatou sofrimento mental considerável oriundo da falta de participação no processo de decisões, rigidez hierárquica, sobrecarga de trabalho, rigidez quanto ao horário, alto nível de exigência de produtividade e no que se refere à disposição do mobiliário - barulho e muitas pessoas trabalhando concomitantemente no mesmo local.

O inevitável processo de implantação das novas tecnologias deu-se de forma vertical, sem a necessária discussão com os atores operacionais ou a preparação dos servidores para vivenciarem o novo modelo organizacional. Não houve nenhuma política institucional nesse sentido. Teoricamente, houve tempo em que se acreditava que a mecanização ou a robotização dos processos de produção, notadamente os mecânicos, deixaria mais tempo livre para a produção intelectual, o pensamento e a contemplação, mas não é o que se vê na prática. O processo de substituição do homem pela máquina (computador) trouxe consigo enorme carga de medo, insegurança, angústia, tristeza e insatisfação, pois feito sob a égide do regime capitalista, de concentração de renda e de poder. O resultado foi uma popularização do até então quase desconhecido fenômeno do estresse e das doenças cardiovasculares dele resultantes, até bem pouco tempo reservadas àqueles com mais experiência de vida.

Pode-se querer comparar o trabalho na era do predomínio tecnológico com aquele do início do século XX, das fábricas insalubres, das linhas de montagem ou mesmo com o trabalho da era pré-industrial, onde prevaleciam os veículos de tração animal e a força braçal e concluir, açodadamente, que agora não há sofrimento ou motivos para queixas, mas não se pode esquecer que hodiernamente o ambiente de trabalho tem condições de se constituir em um espaço para a realização pessoal e 
profissional, enfim, para o crescimento, ou se constituir em uma nova fonte de opressão, de exploração e, principalmente, em um novo modelo de exclusão.

Para concluir, ressalta-se que este trabalho deve ser visto sob a luz das suas limitações, trata-se de pesquisa realizada apenas em uma instituição, com uma parcela dos servidores de determinada coordenadoria. Além disso, não foi possível, dada a exigüidade do tempo para a pesquisa e os objetivos do estudo, buscar maiores informações sobre, por exemplo, as reações externas dos servidores, como tabagismo, alcoolismo, absenteísmo, envolvimento com drogas, etc., mas pretende-se que a ausência dessas abordagens não o descaracteriza por completo, podendo constituir-se em fonte de informação ou ponto de partida para aqueles que pretendem pesquisar mais profundamente sobre o tema prazer e sofrimento no trabalho no setor público, pois traz fatos que exteriorizam situações vivenciadas pelos servidores em seu dia-a-dia.

Informa-se que as entrevistas foram realizadas quando da eclosão, pelos menos em termos de divulgação, da crise econômico-financeira mundial (outubro/novembro/dezembro de 2008) e seus efeitos, período em que houve notícias de demissões em massa em muitas empresas, férias coletivas, quebradeiras de instituições financeiras, retiradas de capitais (especulativos, diga-se de passagem) de países emergentes, grandes perdas em aplicações nas bolsas de valores e grandes variações cambiais, o que pode ter contribuído para um estado de medo/letargia do pior além de gratidão por se ter um emprego, influenciando, inevitavelmente na avaliação dos entrevistados.

Assim, conclui-se que a fonte das relações de prazer/sofrimento no trabalho na instituição pesquisada está principalmente focada na questão da organização do trabalho e na forma como foram implantadas as mudanças estruturais e administrativas, dimensões que causaram maiores transtornos/sofrimentos, e, a estabilidade no emprego, é a maior responsável pela esperança de realização profissional e pelo orgulho de servir a uma organização do Poder Judiciário federal tão bem qualificada pela sociedade, fato que justifica o seu destaque no quesito prazer/satisfação no trabalho. 


\section{REFERÊNCIAS}

BALLONE e GJ, Moura - Estresse e Trabalho - in PsiqWeb, internet, disponível em www.psiqweb.med.br, consultado em 02/12/2008.

BRESSER-PEREIRA, L.C.: SPINK, P. Gestão do setor público: estratégia e estrutura para um novo estado. In (Org.) Reforma do Estado e Administração

Pública Gerencial. Rio de Janeiro: FGV, 1998, p. 21-38.

DEJOURS C. A banalização da injustiça social. ed. Rio de Janeiro: FGV, 2007.

FERREIRA, M.C. Qualidade de vida no trabalho. In: CATTANI, A.D.; HOLZMANN, L. Dicionário de trabalho e tecnologia. Porto Alegre: Ed. da UFRGS, 2006. pp. 219-222.

FERREIRA, C. M. M. Crise e reforma do Estado: uma questão de valorização do servidor, Revista do Serviço Público, Ano 47, Volume 120, Número 3: Set-Dez 1996.

FERREIRA, M. C.; MENDES, A. M. Só de pensar em vir trabalhar, já fico de mauhumor: atividade de atendimento ao público e prazer-sofrimento no trabalho. Estudos de Psicologia, Natal - RN, v. 6, n. 1, 2001, p. 93-104.

FERREIRA, M. C.; MENDES, A. M. Trabalho e riscos de adoecimento: o caso dos auditores-fiscais da Previdência Social brasileira. Brasília: Ler, Pensar, Agir, 2003, p. $41-43,48$.

GOODSELL, C.T. (1993), Reinvent government or rediscover it?: Public Administration Review, vol 53, n.1.

MADUREIRA \& Rodrigues. Comportamento Organizacional e Gestão, 2006, Vol. $12, \mathrm{n}^{\circ} 02$.

MAIR, J. Chega de Oba-Oba. São Paulo: Martins Fontes, 2005.

MARTINS, S. R. Subjetividade e adoecimento por Dorts em trabalhadores de um banco público em Santa Catarina. In. MENDES, A. M.. Psicodinâmica do Trabalho: teoria, método e pesquisas. São Paulo: Casa do Psicólogo, 2007.

MENDES, A. M. (org). Psicodinâmica do Trabalho: teoria métodos e pesquisas. São Paulo: Casa do Psicólogo, 2007.

MENDES, A. M e Tamayo Á. Valores organizacionais e prazer-sofrimento no trabalho. Psico-USF, v. 6, n. 1, 2001, p. 39-46. 
MENDES, A. M; FERREIRA, M. C. Gestão com pessoas focadas na qualidade de vida no trabalho: Bem-estar, uma tarefa de todos. In: Fórum Qualidade de Vida: Trabalhando e vivendo com qualidade, Brasília, 2004, p. 3-8.

OSBORNE, D. \& GAEBLERR, T. (1994), Reinventando o governo - como o espírito empreendedor está transformando o governo. Brasília: MH Comunicação. 


\section{ANEXO I \\ ROTEIRO DA ENTREVISTA}

1) O que lhe vem à mente quando você ouve a palavra trabalho?

2) Quais os seus sentimentos em relação ao seu trabalho nessa organização?

3) Quando você acorda e pensa em vir trabalhar, o que passa pela sua cabeça?

4) Como você faz para enfrentar seu dia-a-dia no trabalho?

5) Como você avalia as condições de trabalho oferecidas? (Ambiente, recursos materiais, carga horária, salário, etc.)

6) O trabalho tem afetado seu comportamento? E sua saúde? Como?

7) Como é sua relação com a chefia? E com os colegas?

8) Antigamente, trabalhar aqui era melhor ou pior? Por quê?

9) Como você avalia a organização do trabalho na Coordenadoria de Taquigrafia? O que, em sua ótica, necessitaria ser mudado?

10) Para concluir, resuma seu trabalho em duas palavras. 